\title{
Fruit size and firmness QTL alleles of breeding interest identified in a sweet cherry 'Ambrunés' $\times$ 'Sweetheart' population
}

\author{
Alejandro Calle ${ }^{1,2}$, Francisco Balas ${ }^{3}$, Lichun $\mathrm{Cai}^{4}$, Amy Iezzoni ${ }^{4}$, Margarita López- \\ Corrales $^{3}$, Manuel J. Serradilla ${ }^{5}$, Ana Wünsch ${ }^{1,2}$ \\ ${ }^{1}$ Unidad de Hortofruticultura, Centro de Investigación y Tecnología Agroalimentaria de Aragón \\ (CITA). Avda. Montañana 930, 50059, Zaragoza, Spain \\ ${ }^{2}$ Instituto Agroalimentario de Aragón-IA2 (CITA-Universidad de Zaragoza), 50013 Zaragoza, \\ Spain \\ ${ }^{3}$ Centro de Investigación Finca La Orden-Valdesequera (CICYTEX), Área de Hortofruticultura, \\ Junta de Extremadura, Autovía Madrid-Lisboa s/n, 06187, Badajoz, Spain \\ ${ }^{4}$ Department of Horticulture, Michigan State University, 1066 Bogue St, East Lansing, MI \\ 48824-1325, USA \\ ${ }^{5}$ Área de Vegetales, Instituto Tecnológico Agroalimentario de Extremadura, Centro de \\ Investigaciones Científicas y Tecnológicas de Extremadura, Avenida Adolfo Suárez s/n, 06007, \\ Badajoz, Spain
}

Corresponding author: Ana Wünsch (awunsch@aragon.es)

Keywords: Prunus avium, firmness, size, QTL, breeding, 'Ambrunés'.

\begin{abstract}
The Spanish local cultivar 'Ambrunés' stands out due to its high organoleptic quality and fruit firmness. These characteristics make it an important parent for breeding cherries with excellent fresh and post-harvest quality. In this work, an $\mathrm{F}_{1}$ sweet cherry population $(n=140)$ from 'Ambrunés' $\times$ 'Sweetheart' was phenotyped for two years for fruit diameter, weight and firmness and genotyped with the RosBREED cherry Illumina Infinium ${ }^{\circledR} 6 \mathrm{~K}$ SNP array v1. These data were used to construct a linkage map and to carry out QTL mapping of these fruit quality traits. Genotyping of the parental cultivars revealed that 'Ambrunés' is highly heterozygous, and its genetic map is the longest reported in the species using the same SNP array. Phenotypic data analyses confirmed a high heritability of fruit size and firmness and a distorted segregation towards softer and smaller fruits. However, individuals with larger and firmer fruits than the parental cultivars were observed, revealing the presence of alleles of breeding interest. In contrast to other genetic backgrounds in which a negative correlation was observed between firmness and size, in this work, no correlation or low positive correlation was detected between both traits. Firmness, diameter and weight QTLs detected validated QTLs previously found for the same traits in the species and major QTLs for the three traits were located on a narrow region of LG1 of 'Ambrunés'. Haplotype analyses of these QTLs revealed haplotypes of breeding interest in coupling phase in 'Ambrunés', which can be used for the selection of progeny with larger and firmer fruits.
\end{abstract}


Sweet cherry (Prunus avium L.) is almost exclusively cultivated for its edible fruit. Consumer surveys in diverse geographical regions have identified large fruit, dark skin and uniformity of color, firmness, sweetness, sourness, flavor intensity, soluble solid concentration and titratable acidity as the main aspects of consumer acceptability for sweet cherry (Cliff et al. 1995; Crisosto et al. 2003; Chauving et al. 2009). Of these, fruit firmness is one of the most important attributes that consumers use in judging sweet cherry acceptability (Guyer et al. 1993). However, grower's profitability also directly depends on fruit size as the vast majority of sweet cherries are sold as fresh fruit with large size achieving a premium price (Whiting et al. 2006). The fruit quality that the consumer experiences depends on biochemical and sensory changes in color, flavor and texture during fruit development and ripening, as well as during post-harvest storage (Crisosto et al. 2003; Serrano et al. 2005). Therefore, acceptable post-harvest performance throughout the supply chain is an important aspect of fruit quality (Gallardo et al. 2015, Romano et al. 2006), and efforts are taken to maintain high fruit firmness, such as gibberellic acid treatment or rapid fruit cooling $\left(<1^{\circ} \mathrm{C}\right)$ (Crisosto et al. 1995; Zoffoli et al. 2017).

Cultivation and trading of sweet cherry is an important economic activity in different regions of Spain, with major production in the Jerte Valley (Cáceres). The tradition of sweet cherry production in this area is based on the cultivation of landraces, which are highly adapted to soil and climate conditions. Among these landraces, the cultivar 'Ambrunés' is the most extensively grown cultivar due to its outstanding fruit quality and excellent post-harvest characteristics (Alique et al. 2005; Serradilla et al. 2012) making it the basis of the Protected Designation of Origin (POD) 'Cereza del Jerte'. 'Ambrunés' is a vigorous, self-incompatible, early flowering and very late ripening (+31 days after 'Burlat') cultivar. The fruits are heart-shaped, of medium size, garnet skin colour with orange flesh, harvested without the peduncle and exhibits high resistance to fruit cracking (Gella et al. 2001; Quero-García et al 2017). Also, fruit firmness is well maintained during ripening providing outstanding post-harvest quality (Serradilla et al. 2010). Because of its importance in this region, 'Ambrunés' has been extensively studied to describe its physicochemical and nutritional composition (Bernalte et al. 1999; Serradilla et al. 2011, 2016; Garrido et al. 2014), post-harvest characteristics (Alique et al. 2005; Serradilla et al. 2011, 2013), and biochemical (Serradilla et al. 2008) and genetic protocols for authentication (Serradilla et al. 2013, 2014). However, 'Ambrunés' has some disadvantages in modern orchards, such as a lack of homogeneity among individuals and irregular yields over the years (LópezCorrales et al. 2003). Because of its adaptation to the Jerte Valley conditions, its excellent fruit and post-harvest quality, and evidence that it is genetically distant from most of the sweet cherry germplasm used in breeding (Wünsch and Hormaza 2002; Cabrera et al. 2012), 'Ambrunés' is an important cultivar used in sweet cherry breeding.

Most sweet cherry fruit quality traits exhibit quantitative variation (Lamb 1953; Fogle 1961) with size and firmness being two of these important fruit quality traits and therefore essential traits in every breeding program (Dirlewanger et al. 2009). Fruit size and weight are highly correlated, thus larger fruits have more weight (Whiting et al. 2006), and it is usual to find the terms weight, diameter and length used indistinctly in literature regarding sweet cherry denoting fruit size. Several works have studied the genetics of fruit size in sweet cherry. Zhang et al. (2010) identified QTLs related to fruit diameter and weight on linkage groups (LGs) 2 and 6 using a 'New York 54' $\times$ 
'Emperor Francis' population. Rosyara et al. (2013) using four sweet cherry populations ('New York 54' × 'Emperor Francis'; 'Regina' × 'Lapins'; 'Namati' × 'Summit'; 'Namati' $\times$ 'Krupnoplodnaya') identified four additional fruit weight QTLs on LGs 1, 2, 3 and 6, and validated the two fruit size QTLs described by Zhang et al. (2010). Furthermore, using two additional populations ('Regina' $\times$ 'Lapins' and 'Regina' $\times$ 'Garnet'), Campoy et al. (2015) reported a new major fruit weight QTL on LG5.

Regarding fruit firmness, Campoy et al. (2015) reported the first QTL analysis in sweet cherry ('Regina' $\times$ 'Lapins' and 'Regina' $\times$ 'Garnet' populations). Firmness QTLs in this work were found on all LGs (except LG7), with a major QTLs found on LG2. More recently, Cai et al. (2019) carried out firmness QTL analyses in three sweet cherry populations ('Fercer' $\times$ ' $\mathrm{X}$ ' $\mathrm{F}_{1}$ population, the INRA sweet cherry germplasm collection and RosBREED pedigreed population). A major firmness QTL on LG4 ( $q P$ FF4.1), explaining 54.0 to $84.6 \%$ of phenotypic variation, was found (Cai et al. 2019). Additional minor QTLs on LGs 1, 2, 5, 6 and 8 were also detected (Cai et al 2019). Haplotype analysis of $q P-F F 4.1$ revealed a dominant effect of 'soft' alleles over 'firm' ones, and most of the bred cultivars were homozygous for 'firm' alleles whereas mazzards were homozygous for 'soft' alleles (Cai et al. 2019). In silico firmness candidate gene analyses have revealed potential candidate genes related with plant cell wall modification and hormone signalling pathways (Campoy et al. 2015; Cai et al. 2019). Endopolygalacturonase (endoPG) genes have been reported as candidate genes involved in fruit softening and flesh texture control in apple and peach (Costa et al. 2010; Gu et al. 2016).

The objective of this work was to investigate the genetic basis of fruit firmness from 'Ambrunés' and determine if fruit firmness and size are correlated in 'Ambrunés' offspring, with the ultimate goal of enabling marker assisted selection (MAS) of this trait in sweet cherry. Given the relationship observed between fruit firmness and size (Campoy et al. 2015), fruit size was also investigated. To achieve this goal, an $F_{1}$ sweet cherry population ('Ambrunés' $\times$ 'Sweetheart'), along with the parental genotypes that come from two distinct genetic pools (Wünsch and Hormaza 2002; Cabrera et al. 2012), were used. This population was phenotyped for two years for three fruit quality traits (weight, diameter/size and firmness/texture) and genotyped with the RosBREED cherry 6K SNP array v1 to enable the construction of a linkage map for QTL discovery.

\section{MATERIALS AND METHODS}

\section{Plant material}

The $\mathrm{F}_{1}$ sweet cherry population $(\mathrm{N}=140)$ was from the cross of 'Ambrunés' $\left(S_{3} S_{6}\right) \times$ 'Sweetheart' $\left(S_{3} S_{4}\right.$ ') $(\mathrm{A} \times \mathrm{S})$, where the two parents are derived from two distinct genetic pools (Wünsch and Hormaza 2002). This family and the parental cultivars were maintained in the facilities of 'Centro de Investigaciones Científicas y Tecnológicas de Extremadura (CICYTEX) in the Jerte Valley (Cáceres, Spain). The A $\times$ S cross was made in 2009 and offspring individuals were planted in the field in 2010. 'Ambrunés' is a landrace traditionally cultivated in the Jerte Valley and the most cultivated variety in this area. It shows both outstanding organoleptic quality and great post-harvest aptitude, based on its capacity to maintain firmness through time (Serradilla et al. 2012). 'Sweetheart' is a commercial cultivar from the Pacific Agri-Food Research Centre 
(PARC) cherry breeding program in Summerland (BC, Canada) that stands out for selffertility and late ripening (Lane and MacDonald 1996).

\section{Fruit size and firmness phenotyping}

Phenotyping of fruit weight, diameter and firmness was done for two consecutive years (2015 and 2016) for $\mathrm{A} \times \mathrm{S}$ individuals and the parental cultivars. Fruits were harvested at the optimal ripening stage based on the assessment of skin color, texture and taste, both years (Chavoshi et al. 2014). In the first year (Y1), 10 fruits per tree were phenotyped, while 25 fruits per tree were phenotyped in the second year (Y2). Fruits of each tree were weighted and measured at its longest axis (opposite to suture axis) using a calliper. To evaluate fruit firmness, a texturometer (TA.XT2i Texture Analyser, Stable Microsystems, Godalmimg, UK) was used. The texturometer was adjusted to measure the force needed to deform a fruit $3 \%$ of its diameter using a $70 \mathrm{~mm}$ aluminium plate (Martínez-Esplá et al. 2014). Firmness measures were performed at two different points of each fruit: on the dorso-ventral axis (traversing the suture) and on the medio-lateral axis. The slope was determined in the linear zone of the forcedeformation curve and the results are expressed as $\mathrm{N} / \mathrm{mm}$.

The phenotypic data was analysed to estimate the mean, standard deviation and distribution of each trait in both years. Additionally, analysis of the linear correlation among traits and nonparametric analysis of variance (ANOVA) were carried out. Broad sense heritability $\left(H^{2}\right)$ was estimated using the equation $H^{2}=\frac{\sigma_{g}^{2}}{\sigma_{g}^{2}+\frac{\sigma_{e}^{2}}{n}}$, where $\sigma_{g}^{2}$ is the genetic variance in the $\mathrm{F}_{1}$ family, $\sigma_{e}^{2}$ is the environmental variance and $n$ is the number of years. These statistical analyses were performed using SPSS ${ }^{\circledR}$ statistics v21.0.0 (IBM, Chicago, IL, USA) and R v3.4.1 (R Core Team 2017).

\section{SNP genotyping and linkage map construction}

Genomic DNA from the $\mathrm{A} \times \mathrm{S}$ individuals and the parental cultivars was extracted using DNeasy Plant Mini Kit ${ }^{\circledR}$ (Qiagen N.V., Hilden, Germany). DNA quantification and SNP genotyping of all the individuals and the parental cultivars was done at CEGEN-PRB2-ISCIII (Madrid, Spain). SNP genotyping was carried out using the RosBREED cherry 6K Illumina Infinium ${ }^{\circledR}$ SNP array v1 (Peace et al. 2012). The SNP genotypes were clustered, reviewed and filtered using the Genotyping Module of GenomeStudio $^{\circledR}$ software, using the build-in algorithm 'Gentrain2' for all samples with GenCall score above 0.15 (v2011.1, Illumina Inc., San Diego, CA, USA). The SNP data were clustered using the $\mathrm{A} \times \mathrm{S}$ individuals and a set of 45 sweet cherry accessions, to maximize allelic diversity (Martínez-Royo and Wünsch 2014; Calle et al. 2018). A duplicate individual genotype was included in each 96 plate as a control. Identical SNP genotypes were identified for replicated individuals, confirming the SNP scan quality and reproducibility. The SNPs incorrectly clustered for the individuals of $A \times S$ population were revised and manually edited when possible. Paternity analysis to confirm hybrid identity of all the progeny was performed using the P-P-C (ParentParent-Child) module of GenomeStudio. ASSIsT v1.01 software (Di Guardo et al. 2015) was used to filtered SNP markers and assigned input data format prior to linkage mapping. 
Linkage map construction was performed using JoinMap ${ }^{\circledR}$ software (v4.1, Kyazma B.V., Wageningen, The Netherlands; van Ooijen 2006) following the 'Twostep strategy' described by Tavassolian et al. (2010). Minimum independence of LOD, recombination frequency, maximum likelihood mapping algorithm and Kosambi's mapping function (Kosambi 1944) were used for map construction following the details described by Calle et al. (2018) for a cross-pollinated population. Markers showing distorted segregation ratios $(\mathrm{p}<0.01)$ from expected Mendelian segregation were eliminated when they were not flanked by other markers showing a similar distortion. The genetic positions of mapped SNPs were compared with their physical positions in the peach genome v2.0.a1 (Verde et al. 2017).

\section{QTL mapping and haplotype analysis}

QTL analysis was performed for the three phenotyped traits (weight, diameter, and firmness) on the parental maps in both years. QTL mapping was carried out using MapQTL $^{\circledR}$ (v.6.0, Kyazma B.V., Wageningen, The Netherlands; van Ooijen 2009), through the interval mapping method (Lander and Botstein 1989) and MQM mapping (Jansen 1993, 1994; Jansen and Stam 1994). To establish the LOD significance threshold for each QTL in each linkage group (LG), a permutation test was done, also using MapQTL ${ }^{\circledR}$, at a significance level of 95\% ( $\left.<<0.05\right)$ using 10,000 permutations (Lander and Botstein 1989; van Ooijen 1992). Graphical representations of LGs and QTLs were obtained using MapChart software (Voorrips 2002).

QTL haplotypes (i.e. alleles) were constructed for the QTLs that were detected in both years. SNP markers spanning the QTL regions were selected to determine parental haplotypes. Progeny showing recombination in these QTL regions were eliminated from the analysis. Mean phenotypic values of each QTL haplotype were estimated in the remaining $\mathrm{A} \times \mathrm{S}$ population individuals. ANOVA calculations and Student's t-test $(\mathrm{p}<0.05)$ were done using SPSS $^{\circledR}$ statistics v21.0.0 software (IBM, Chicago, IL, USA) to compare mean values of the different haplotypes.

\section{RESULTS}

\section{Phenotype mean, distribution, heritability and correlation}

Phenotyping for fruit weight, diameter and firmness in $\mathrm{A} \times \mathrm{S}$ was carried out for $94(67 \%)$ and 99 (71\%) individuals each year (Y1 and Y2, respectively), with a total of 117 trees evaluated in the two years. Fruit weight and diameter mean values in the progeny were not significantly different between years, despite the fact that in Y1 ten fruits per individual were phenotyped, and 25 fruits per individual were used in Y2 (Online Resource 1). However, for fruit firmness, a significant difference was observed between Y1 and Y2 (Student's t-test; $\mathrm{p}<0.05$ ), with firmness being higher in Y1 (1.7 $\mathrm{N} / \mathrm{mm}$ in $\mathrm{Y} 1$ and $1.5 \mathrm{~N} / \mathrm{mm}$ in Y2; Online Resource 1). This slight difference may be due to the larger number of phenotyped fruits in Y2, which may have achieved a better accuracy, or else environmental conditions of different harvest years may have influenced this trait. Broad-sense heritability $\left(H^{2}\right)$ ranged from 0.63 to 0.75 for the three traits, being largest $\left(H^{2}=0.75\right)$ for firmness (Online Resource 1). 
Progeny distributions for the three traits measured revealed that weight (Shapiro Wilk test; Prob<W: 0.345 in Y1; Prob<W: 0.155 in Y2) and diameter (Prob<W: 0.970 in Y1; Prob<W: 0.295 in Y2) fit the expectation of normality; whereas, firmness exhibited a highly skewed distribution to softer fruits, and therefore did not fit a normal distribution (Y1 Prob $<\mathrm{W}:<0.0001$; Y2 Prob $<\mathrm{W}:<0.0001$ ). Additionally, progeny resulting from positive transgressive segregation for firmness were observed in both years, while for diameter and weight, similar transgressive progeny were only observed in the second year. However, negative transgressive segregation was observed for all the traits both years (Fig 1). In fact, the population means were lower than the parental means for the three traits both years.

Pearson's correlation coefficients ( $r$ ) were calculated among the three traits in both years (Fig 2). As expected, a highly significant positive correlation $(\mathrm{p}<0.01)$ was observed between diameter and weight in both years ( $r=0.954$ in $Y 1 ; r=0.962$ in Y2). In addition, a low significant positive correlation was observed between firmness and diameter in the second year $(\mathrm{r}=0.384, \mathrm{p}<0.01$ in $\mathrm{Y} 2)$, indicating that in the second year, progeny with wider fruits tended to have firmer fruit. No significant correlation $(p<0.01)$ was detected between firmness and weight in either year.

\section{SNP genotyping and linkage map construction}

From 5696 total SNPs on the array, 5360 (94\%) and 5377 (94\%) SNPs could be genotyped in 'Ambrunés' and 'Sweetheart', respectively. 'Ambrunés' exhibited higher heterozygosity than 'Sweetheart', with 641 heterozygous SNPs in 'Ambrunés' and 450 in 'Sweetheart'. From the genotyped markers in the A $\times$ S population, 4446 (78\%) were monomorphic, $355(6 \%)$ failed, and the remaining $895(16 \%)$ were polymorphic and informative, and therefore used for linkage map construction.

The parental linkage maps for 'Ambrunés' and 'Sweetheart' consisted of 463 and 254 SNPs, respectively (Online Resource 2). Both maps had the expected eight LGs, and covered 867.8 and $529.1 \mathrm{cM}$, respectively (Online Resource 2 - 4). Due to the relatively high level of heterozygosity in 'Ambrunés', a larger number of markers were placed on the linkage map, and all eight linkage groups were longer than those for 'Sweetheart' (Online Resource 2 and 3). 'Sweetheart's LGs 3, 4 and 7 had very low coverage with 12 to 14 SNPs, and the 'Sweetheart' linkage map also exhibited large regions with no segregating markers suggesting that these regions are homozygous (Online Resource 2 and 3). Average marker distance was similar in both parental maps (2.1 and $2.4 \mathrm{cM}$ for 'Ambrunés' and 'Sweetheart', respectively), and large gaps were detected in both, 'Ambrunés' (33.9 cM in LG2, $28.4 \mathrm{cM}$ in LG2) and 'Sweetheart' maps (31.1 cM in LGs 1 and 7) (Online Resource 2 and 3). A group of SNP markers showing distortion from expected Mendelian segregation ratios $(p<0.001)$ were observed at the bottom region of 'Sweetheart' LG6 (Online Resource 3). The AxS consensus map included 820 SNPs, with a total genetic length of $827.6 \mathrm{cM}$ and an average marker distance of $1.0 \mathrm{cM}$ (Online Resource 2 - 4). Consistent with the parental maps, LG1 was the largest with 185 SNPs and covering $184.7 \mathrm{cM}$, while LG5 was the shortest with a genetic distance of $76.2 \mathrm{cM}$ (Online Resource 2 and 3).

The SNP order and position in the 'Ambrunés', 'Sweetheart' and consensus maps were compared with the physical position of the same SNPs in the peach genome v2.0.a1 (Online Resource 4). Despite the high degree of collinearity, some markers, 
nine (1.9\%) SNPs in 'Ambrunés', eight (3.1\%) in 'Sweetheart' and $59(7.2 \%)$ in the consensus map, were mapped to different positions compared to their physical position in the peach genome (Online Resource 4). Most noticeable was an inverted region located at the top of LG5 that included 8 SNPs in 'Sweetheart' and 19 in the consensus map (Online Resource 4). Additionally, nine markers were mapped to different LGs than expected based on the peach genome, with three of the inconsistent markers found in the 'Ambrunés' map and six in the 'Sweetheart' map (Online Resource 5).

\section{QTL analysis}

QTL analysis of the three traits (fruit weight, diameter and firmness) in the two years identified 7 significant QTLs distributed on LGs 1, 3 and 6 (Table 1). Five QTLs were detected both years; one for weight, two for diameter and two for firmness (Table 1; Figure 3). Five QTLs were detected on the 'Ambrunés' map and two on the 'Sweetheart' map.

For fruit weight, two QTLs were detected on LGs 1 and 3 (Table 1) in 'Ambrunés' and 'Sweetheart' maps, respectively. Of these, the most significant was detected both years in 'Ambrunés' LG1 $\left(q P-F W 1.1^{m}\right)$ at 101.8 to $129.9 \mathrm{cM}$ explaining 15.4 and $17.4 \%$ of the phenotypic variation in Y1 and Y2, respectively (Table 1; Fig 3). An additional fruit weight QTL was identified in the second year on 'Sweetheart' LG3. This QTL, $q P-F W 3.1$, explained almost $12 \%$ of the phenotypic variation for that year. For fruit diameter, two QTLs were also detected both years on 'Ambrunés' LG1 ( $q P$ $F D 1.1^{m}$ and $q P-F D 1.2^{m}$ ) (Table 1; Fig 3). Each of these fruit diameter QTLs explained 10.9 to $12.9 \%$ of the phenotypic variation each year. These fruit diameter QTLs mapped $20 \mathrm{cM}$ apart on the 'Ambrunés' parental map (Table 1; Fig. 3), and one of these two fruit diameter QTLs, $q P-F D 1.2^{m}$, mapped to the same position as an 'Ambrunés' fruit weight QTL $q P-F W 1.1^{m}$, also detected in this work (Table 1; Fig 3).

For fruit firmness, three QTLs were identified, two on LG1 and one on LG6 (Table 1). The most significant QTLs $\left(q P-F F 1.1^{m}\right.$ and $\left.q P-F F 1.2^{m}\right)$ were detected both years on LG1 of both parental maps (Table 1; Fig 3). These two QTLs were mapped to a nearby physical positions; however, their confidence intervals do not completely overlap and their QTL peaks are different. As there is no evidence that these two QTLs are the same, beside their close proximity; therefore, they are considered different QTLs in this work. However, different markers are mapped in this region in each parental cultivar, which means that it is possible that both QTLs are the same. QTL $q P-F F 1.1^{m}$ explained 12.7 to $18.8 \%$ of the phenotypic variation in 'Ambrunés', and $q P-F F 1.2^{m}$ explained from 12.9 to $22.5 \%$ of the phenotypic variation in 'Sweetheart' (Table 1). It is noticeable that the QTL in 'Sweetheart' $\left(q P-F F 1.2^{m}\right)$ shows negative values of additive effects $(-0.69$ and $-0.20 \mathrm{~N} / \mathrm{mm})$ in both years, while these values are positive for 'Ambrunés' ( 0.21 and $0.33 \mathrm{~N} / \mathrm{mm}$; Table 1). The location of the fruit firmness QTL on the 'Ambrunés' map, $q P-F F 1.1^{m}$, also overlapping with the 'Ambrunés' fruit diameter QTL $q P-F D 1.1^{m}$. A second firmness QTL, significant only in the second year, was identified on 'Ambrunés' LG6, $q P$-FF6.1, and explained $14.3 \%$ of the phenotypic variation (Table 1; Fig 3). 


\section{Haplotype analysis}

Haplotypes were constructed for the seven QTLs detected (Table 1; Online Resource 6). As expected, 'Sweetheart' was homozygous for all the QTLs, except for $q P-F F 1.2^{m}$ and $q P-F W 3.1$. On the other side, 'Ambrunés' was heterozygous for all QTLs except for firmness and weight QTLs $q P-F F 1.2^{m}$ and $q P-F W 3.1$ (Online Resource 6). The same two SNPs were used to define QTLs $q P-F W 1.1^{m}$ and $q P$ FD1.2 $2^{m}$.

For fruit weight, those progeny individuals that inherited the FW1.1_H2 haplotype from 'Ambrunés' had a significantly higher fruit weight ( one gram increase) in both years compared to those that did not (Table 2). For $q P-F W 3.1$, the only differences between haplotypes were found in Y2 (year in which this QTL was detected), with individuals with the FW3.1_H2 haplotype from 'Sweetheart' exhibiting a higher fruit weight ( 0.6 grams increase). For fruit diameter, those progeny individuals that inherited haplotypes FD1.1_H2 and FD1.2_H2 from 'Ambrunés' had significantly larger fruit diameters both years (1.0 to $1.9 \mathrm{~mm}$ larger; Table 2).

For fruit firmness, inheritance of haplotypes from 'Ambrunés' and 'Sweetheart' for the two QTL on LG1, $q P-F F 1.1^{m}$ and $q P-F F 1.2^{m}$, revealed that progeny individuals with the haplotype combination FF1.1_H2/FF1.2_H2 were on average significantly firmer (from 0.5 to $0.7 \mathrm{~N} / \mathrm{mm}$ ) than those with other haplotype combinations (Table 2). For the firmness QTL $q P$-FF6.1, progeny individuals with the haplotype FF6.1_H1 from 'Ambrunés' also had significantly higher firmness $(0.4 \mathrm{~N} / \mathrm{mm}$ more $)$ than those with FF6.1_H2 (Table 2). Interaction between the two 'Ambrunés' firmness QTLs ( $q P$ $F F 1.1^{m}$ and $q P-F F 6.1$ ) was also examined (Online Resource 7). Progeny individuals with the haplotypes associated with higher firmness from both QTL (FF1.1_H2 and FF6.1_H1) (Table 2) were the firmest both years, with firmness values above $2.0 \mathrm{~N} / \mathrm{mm}$ (Online Resource 7), which was significantly higher than firmness observed in the other genotypes (Online Resource 7).

Haplotype interaction of the four firmness and size QTLs $\left(q P-F W 1.1^{m}, q P\right.$ $F D 1.1^{m}, q P-F D 1.2^{m}$ and $q P-F F 1.1^{m}$ ) found on 'Ambrunés' LG1, revealed that the desirable alleles of breeding interest (haplotype $H 2$ of each QTL) were in coupling phase (Online Resource 8). As an example, offspring L35-33, L35-46, L35-56, L35-60, L35-70 which all have $H 2$ haplotype for these four linked QTL, showed diameter, weight and firmness values larger than the progeny mean and the other haplotype combinations means (Online Resource 8). In addition, the offspring L35-72, that also carried $H 2$ haplotypes for these QTLs, exhibited larger firmness, weight and diameter values than both parents.

\section{DISCUSSION}

\section{SNP genotyping and linkage maps}

The number of heterozygous robust SNP markers genotyped in 'Ambrunés' (641) and 'Sweetheart' (450) was in the range (400-700) reported for other sweet cherry cultivars (Peace et al. 2012) genotyped with the same array, including 'Cristobalina' (526), 'Vic' (483), 'Regina' (603), 'Lapins' (515), 'Black Tartarian' (634) or 'Kordia' (526) (Klagges et al. 2013; Calle et al. 2018). A larger number of heterozygous markers 
were detected in 'Ambrunés' than 'Sweetheart'. 'Ambrunés' is a landrace and is expected to be highly heterozygous, whereas 'Sweetheart' is a commercial cultivar that likely has more homozygous chromosome regions due to breeding within a limited gene pool (Lane and MacDonald 1996). The large number of heterozygous markers in 'Ambrunés' was evidenced in the total genetic length covered by the genetic map, being the largest of all developed in sweet cherry using SNP markers with the RosBREED cherry 6K SNP array (Klagges et al. 2013; Castède et al. 2014; Calle et al. 2018) and Genotyping by Sequencing (GBS) (Guajardo et al. 2015). By comparison, the presence of large putatively homozygous regions in 'Sweetheart' limited the ability to detect QTLs in the $F_{1}$ population. This putative homozygosity was most noticeable on 'Sweetheart' LGs 3 and 4, where very few markers were heterozygous. Similarly, in previous sweet cherry linkage maps developed using the same array, large homozygous regions were also detected in some cultivars and offspring (Calle et al. 2018).

Previous reports have confirmed the collinearity of the cherry and peach genomes with few exceptions (Dirlewanger et al. 2004; Illa et al. 2011; Calle et al. 2018). In this study, collinearity was also observed. However, the comparison of the SNP map positions and their physical positions with the peach genome (Verde et al. 2017) detected an inverted region on the top of LG5 in 'Sweetheart' that had previously been reported in other sweet cherry maps (Calle et al. 2018). In addition, as previously observed (Klagges et al. 2013; Calle et al. 2018), three markers (ss490550875, ss490548697 and ss490550875) mapped on a different LG than in the peach genome, suggesting the need for future investigations.

High segregation distortion was observed at the bottom of LG6 in 'Sweetheart' ( $\mathrm{p}<0.0001)$. This distortion overlaps with the $S$-locus that controls the specificity of the gametophytic self-incompatibility in sweet cherry (reviewed in Herrero et al. 2017). Due to the presence of a common functional $S$-haplotype $\left(S_{3}\right)$ in the two parental cultivars ('Ambrunés', $S_{3} S_{6}$; 'Sweetheart', $S_{3} S_{4}$ ') only 'Sweetheart' $S_{4}$ ' pollen can grow down the 'Ambrunés' style. As a result, segregation distortion against the $S_{3}$ allele and the linked SNPs was observed. A similar segregation distortion, due to crossincompatibility, in the region surrounding the $S$-locus is common in other sweet cherry and Prunus maps (Klagges et al. 2013; Guajardo et al. 2015). This segregation distortion, at the bottom of LG6, does not seem to affect the firmness QTL ( $\left.q P-F F 6.1^{m}\right)$ also on LG6, as this QTL interval is not within $S$-locus segregation distortion region.

\section{Fruit size}

The fruits of 'Sweetheart' were larger and heavier than 'Ambrunés' fruits in both years. These differences were expected since 'Ambrunés' is a landrace and 'Sweetheart' is a commercial variety from a breeding program. In the progeny, normal distributions were observed for weight and diameter, as has also been reported in other sweet and sour cherry studies (Lamb 1953; Fogle 1961; Wang et al. 2000; Zhang et al. 2010; Campoy et al. 2015). Additionally, the observation that the mean fruit size of the offspring was lower than the parental midpoint in our and the other studies, suggests the additive effects of small fruit alleles. If this is the case, MAS for large fruit size alleles would be extremely helpful for breeding. Furthermore, in our study, this suggests that the large fruit size for 'Sweetheart' may be in part due to homozygosity for large-fruited alleles that exhibit recessive gene action. 
The broad-sense heritability $\left(H^{2}\right)$ values of the fruit size traits were moderately high, revealing that a significant portion of the phenotypic variation is due to genetic effects. The heritability for fruit diameter identified herein $\left(H^{2}=0.66\right)$ was similar to that estimated by Zhang et al. (2010) $\left(H^{2}=0.69\right)$. However, the heritability for fruit weight observed in this work $\left(H^{2}=0.63\right)$ was lower than that estimated previously in two populations, 'Regina' $\times$ 'Garnet' $\left(\mathrm{R} \times \mathrm{G} ; H^{2}=0.76\right)$ and 'Regina' $\times$ 'Lapins' $(\mathrm{R} \times \mathrm{L}$; $H^{2}=0.88$ ), evaluated during seven years (Campoy et al. 2015).

The fruit size QTLs identified herein $\left(q P-F W 1.1^{m}, q P-F D 1.1^{m}\right.$ and $\left.q P-F D 1.2^{m}\right)$ were found in a $50.8 \mathrm{cM}(22.5 \mathrm{Mbp})$ region of LG1 of the 'Ambrunés' map. Since $q P$ $F W 1.1^{m}$ and $q P-F D 1.2^{m}$ are overlapping, and both traits are highly correlated, these QTLs may be the same fruit size determinant phenotyped in two different ways in this work. Fruit weight QTLs, FW_Gl and $f w 1.1$ were previously detected in the same region in sweet cherry (Rosyara et al. 2013; Campoy et al. 2015). QTL fw1.1 spanned the three LG1 size QTLs detected in this study $\left(q P-F W 1.1^{m}, q P-F D 1.1^{m}\right.$ and $q P$ $F D 1.2^{m}$ ), while $F W_{-} G 1$ detected by Rosyara et al. (2013) overlapped only with $q P$ $F W 1.1^{m}$ and $q P-F D 1.2^{m}$. In other species, genetic loci associated with fruit size have been observed in homologous regions to this sweet cherry LG1 region. A major and stable QTL for fruit diameter was mapped to LG15 in two different apple populations (Devoghalaere et al. 2012), which correspond to the homologous region of LG1 in the Prunus genome (Illa et al. 2011). Fruit size QTLs in the same LG1 region have also been reported in peach (Da Silva Linge et al. 2015; Quilot et al. 2004; Eduardo et al. 2011), and Cell Number Regulator (CNR) genes have been proposed as candidate genes for fruit size in this LG1 region (De Francheschi et al. 2013). In tomato, a gene that is a member of a $C N R$ family of proteins was found to be the causal gene for a fruit size QTL ( $f w 2.2$ ) (Frary et al. 2000; Pan et al. 2020). A cluster of three of these CNR genes identified in peach, PpCNR09, PpCNR10 and PpCNR11, mapped to the peach chromosome 1 at $\sim 30 \mathrm{Mbps}$ (De Franceschi et al. 2013). This region overlaps with the region spanned by the 'Ambrunés' sweet cherry fruit size QTLs identified in this work $\left(q P-F W 1.1^{m}\right.$ and $\left.q P-F D 1.2^{m} ; 26.47-33.24 \mathrm{Mbp}\right)$.

A larger percentage of the phenotypic variation explained by LG1 size QTLs was observed herein (up to $12.9 \%$ of diameter, and up to $17.4 \%$ of weight) than in earlier works (8.1 to 9.1\%; Rosyara et al. 2013; Campoy et al. 2015), while a similar QTL effect was observed (0.4 to $0.8 \mathrm{~g}$; Rosyara et al. 2013; Campoy et al. 2015). These results indicate that the effect of these LG1 QTLs may vary depending on the alleles at this locus, genetic background and/or environmental conditions. However, our results indicate that when 'Ambrunés' is used as a parent, selecting progeny that contain haplotypes FW1.1_H2, FD1.1_H2 and FD1.2_H2 would result in an overall increase in fruit size in the offspring.

Other fruit size QTLs previously detected in sweet cherry (Zhang et al. 2010; Rosyara et al. 2013; Campoy et al. 2015) were also validated in this work with minor and less stable effect. This was the case for QTL $q P-F W 3.1$ that corresponds to a previously detected QTL for the same trait fw3.2 (Rosyara et al. 2013; Campoy et al. 2015). The major QTL associated with fruit size previously found on LG2 of cherry (Zhang et al. 2010; Rosyara et al. 2013) was not detected in this study. Fruit size SSR marker BPPCT034, which is located within the QTL region is heterozygous in the parental cultivars ('Ambrunés' 222/229 and 'Sweetheart' 222/332; Cai et al. 2017). Additionally, SNP haplotype analysis of this QTL region confirmed that the parental cultivars 'Ambrunés' and 'Sweetheart' are heterozygous for this genomic region and 
have one allele in common (data not shown). Therefore, despite this genomic region is segregating in this family, no phenotypic differences were observed among the progeny classes (data not shown), explaining why the QTL was not detected.

\section{Firmness}

The firmness values for 'Ambrunés' observed in this work, are similar of those described before for the same cultivar at different ripening stages $(1.15 \mathrm{~N} / \mathrm{mm}$ to 2.35 $\mathrm{N} / \mathrm{mm}$; Serradilla et al. 2011, 2012), but 'Sweetheart' firmness values observed were higher than those described previously at the same ripening stage $(1.60 \mathrm{~N} / \mathrm{mm}$; Serradilla et al. 2012). Because firmness is highly dependent on the ripening stage (Serradilla et al. 2012), slight differences in the ripening stage during sampling may account for small firmness differences. However, most likely the elevate area where the plant material is grown (the Jerte Valley at $800 \mathrm{~m}$ above sea level) may have had a relevant effect in fruit firmness in 'Sweetheart'. However, 'Ambrunés' fruits are superior for post-harvest storage, as the firmness of 'Ambrunés' fruits is maintained through post-harvest storage whereas 'Sweetheart' firmness decreases rapidly during conservation (Serradilla et al. 2012).

Previous studies of cherry firmness QTLs used different phenotyping protocols and equipment, and therefore it is not possible to compare the firmness values across studies. In the works by Campoy et al. (2015) and Cai et al. (2019), Durofel ${ }^{\circledR}$ and BioWorks FirmTech 2, respectively, were used for phenotyping, while a texturometer was used in this study. Firmness distribution in the populations studied by Campoy et al. (2015) fitted to normal distribution in all evaluated years, whereas the $A \times S$ population shows a skewed segregation to softer fruits in both years, as previously observed in 'Fercer' $\times$ ' $X$ ' (Cai et al. 2019), probably due to dominance of alleles of softer fruit. Firmness heritability identified in this work (0.75) was within the range previously observed in other sweet cherry populations for this trait (0.73-0.97) (Campoy et al. 2015; Cai et al. 2019).

In this work, two major QTLs for fruit firmness, one in each parental cultivar, were detected on LG1 $\left(q P-F F 1.1^{m}\right.$ and $\left.q P-F F 1.2^{m}\right)$. They were located nearby according to their physical positions on the peach genome, but on different parental maps. Given that each parental map contains different SNP markers, it is unclear if they are the same QTL or two different closely linked QTLs. Further efforts, such as increasing population size and marker density, will be able to determine whether this genomic region contains one or two fruit firmness QTLs. In fact, a firmness QTL in the same region was previously reported by Campoy et al. (2015) in an $F_{1}$ population, and by Cai et al. (2019) in a genome-wide fruit firmness association study of a sweet cherry germplasm collection. Again, as observed for fruit size QTLs on LG1, the proportion of variance explained by this QTL was lower in earlier works (6.4\%; Campoy et al. 2015) than reported in our population (12.7 to $22.5 \%)$. It is relevant to notice that for this QTL, a negative additive effect was observed for 'Sweetheart' whereas a positive additive effect was found in 'Ambrunés'. Previously, a negative additive effect was also observed (Campoy et al. 2015), thus revealing that 'Ambrunés' carries alleles which increase firmness while 'Sweetheart' and other related cultivars may carry alleles that decrease firmness. In apple, a major and stable QTL controlling fruit firmness was mapped to LG15 of the Malus genome in various populations (Longhi et al. 2012; Chagné et al. 2014). This region of the Malus genome (LG15) is homologous to LG1 of 
the Prunus genome (Illa et al. 2011), suggesting a syntenic region determining fruit firmness across these two genera.

Fruit firmness candidate genes have been investigated in Rosaceae species like peach and apple (Costa et al. 2010; Gu et al. 2016). In these species, enzymes associated with cell wall organization have been proposed as the strongest candidate genes associated with fruit firmness variations (Brummell et al. 2004). Endopolygalacturonase (endoPG) genes, implicated in fruit softening through cell wall modifications (Brummel and Harpster 2001), encode enzymes involved in fruit softening and flesh texture in apple and peach, respectively (Costa et al. 2010; Gu et al. 2016). An endoPG gene (Prupe.1G167700.1) located at $13.6 \mathrm{Mbp}$ of chromosome 1 of peach genome v2.0.a1 assembly (Verde et al. 2017), within the region spanned for major firmness QTLs is found on LG1 (12.61 to $24.18 \mathrm{Mbp}$; peach genome v2.0.a1). This gene may be a fruit firmness candidate gene in sweet cherry, as in other Rosaceae species (Costa et al. 2010; Leida et al. 2011; Atkinson et al. 2012; Gu et al.2016).

The other firmness QTL was detected on 'Ambrunés' LG6 ( $q$ P-FF6.1). In prior studies, Campoy et al. (2015) and Cai et al. (2019) reported this same QTL using other plant material. An endoPG homolog gene has been proposed as a candidate gene for fruit firmness control at this QTL (Campoy et al. 2015). We have observed an additional predicted endoPG gene (Prupe6G155200.1) in the peach genome v2.0.a1 assembly (Verde et al. 2017) within the region spanned by this QTL, which may also be a candidate gene for fruit firmness at this QTL. Another major firmness QTL reported on LG4 of sweet cherry (Cai et al. 2019) was not detected in this work. 'Ambrunés' and 'Sweetheart' are homozygous for the same firm fruit allele $(H 1 H 1)$ of this QTL ( $q P$ FF4.1; Cai et al. 2019), explaining why this QTL was not detected in this study, and why these two cultivars are quite firm.

Favorable haplotypes for the firmness QTLs were identified in this study and increased fruit firmness may be achieved by combining these desirable haplotypes (FF1.1_H2/FF1.2_H2 and FF6.1_H1). This increase in firmness was observed for the 'Ambrunés' $q P-F F 1.1^{m}$ and $q P-F F 6.1$, where progeny individuals with the two firmness haplotypes ( $F F 1.1 \_H 2$ and $\left.F F 6.1 \_H 2\right)$ were associated with an increase in firmness. In addition, 'Ambrunés' haplotypes for QTLs on LG1 associated to fruit size and firmness increase were found on coupling phase, allowing to select a unique 'Ambrunés' LG1 haplotype region to gain fruit size and firmness.

\section{Fruit size and firmness correlation and interaction}

Results showed transgressive positive segregation for the three traits in Y2. Campoy et al. (2015) described a significant negative correlation between firmness and weight for two sweet cherry $F_{1}$ populations. This negative correlation means that selecting for heavier fruits will result in softer fruits, thus providing a complex scenario for fruit quality breeding in sweet cherry. As herein, Chavoshi et al. (2014) and Piaskowski et al. (2018) observed a moderate positive correlation between fruit firmness and size in the plant material of the RosBREED sweet cherry crop reference set. These results indicate that distinct genetic backgrounds show different relationships between size and firmness, probably due to the presence of diverse alleles controlling these traits in the different plant materials. The absence of a negative correlation between these traits in this work, and the observation of slight positive correlation 
between firmness and diameter, could be due to favorable QTL alleles of 'Ambrunés' LG1 being on coupling phase, indicating it is possible to select for larger and firmer fruits at the same time in this genetic background $(\mathrm{A} \times \mathrm{S}$; Online Resource 8$)$. These results confirm that 'Ambrunés' could be a useful cultivar for firmness and fruit quality breeding. The overlapping of the firmness $\left(q P-F F 1.1^{m}\right)$ and diameter $\left(q P-F D 1.1^{m}\right)$ QTLs on LG1 of 'Ambrunés' also is consistent with the correlation between both traits, indicating a possible common genetic determinism. Previous co-localizations of fruit size and firmness QTLs were also reported in sweet cherry and in peach (Campoy et al. 2015; Zeballos et al. 2016).

In this study, the analysis of fruit size and firmness in progeny of a $F_{1}$ population with parents from two unrelated sweet cherry genetic pools (Wünsch and Hormaza 2002) resulted in the identification of QTL haplotypes that would be desirable for breeding. In particular, haplotypes for LG1 QTLs derived from 'Ambrunés' would be important targets for pyramiding and combining favorable alleles from this cultivar. The finding that these three QTLs are found in 'Ambrunés' and that the favorable alleles on LG1 are in coupling phase reveal the potential of this cultivar for breeding for fruit size and firmness. The lack of QTLs identified from this $F_{1}$ population in both years from 'Sweetheart', could be due to this cultivar being homozygous for these QTL regions. In addition, further analyses in larger populations will allow a fine mapping of these traits to narrow the QTL regions, and therefore obtain the desirable number of recombinant individuals to identify candidate genes within QTL interval. Also, the observation of large prevalent homozygous regions in 'Sweetheart' is a disadvantage for QTL discovery. However, as this cultivar is self-compatible, it would be possible to develop $\mathrm{F}_{2}$ populations from individuals of $\mathrm{A} \times \mathrm{S}$, to investigate the genetic effects of alleles hypothesized to be homozygous in 'Sweetheart' and 'Ambrunés'.

\section{DECLARATIONS}

\section{Funding}

This work was funded by Spanish Government 'Ministerio de Economía Industria y Competitividad', 'Agencia Estatal de Investigación' (AEI), and 'Instituto Nacional de Investigación y Tecnología Agraria y Alimentiaria (INIA) by research projects RTA2015-00027-00-00, and FEDER funds; and by 'Grupo de Investigación de la Comunidad de Aragón' A12-17R ('Fruticultura. Caracterización, Adaptación y Mejora Genética') of 'Departamento de Innovación, Investigación y Universidad', 'Gobierno de Aragón'. SNP genotyping was carried out at CEGEN-PRB2-ISCIII; supported by grant PT13/0001, ISCIII-SGEFI/FEDER. A Calle was funded by 'Departamento de Innovación, Investigación y Universidad', 'Gobierno de Aragon' by $\mathrm{PhD}$ programme 'Subvenciones destinadas a la contratación de personal investigador en formación 20152019'. L. Cai was supported by the USDA-NIFA-Specialty Crop Research Initiative project, RosBREED: Enabling marker-assisted breeding in Rosaceae (2009-51181- 
588

589

590

591

592

593

594

595

596

597

598

599

600

601

602

603

604

605

606

607

608

609

610

611

612

613

614

615

616

617

618

619

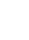

14

05808) and RosBREED 2: Combining disease resistance with horticultural quality in new rosaceous cultivars (2014-51181-22378).

\section{Conflicts of interest}

The authors declare no conflict of interest

\section{Availability of data and material}

The linkage map and QTL datasets generated for this study can be found in the Genome Database for Rosaceae. (https://www.rosaceae.org/publication_datasets). Accession number: tfGDR1043.

(1)

\section{Code availability}

Not applicable

\section{Authors' contributions}

MLC provided plant material, FB and MS carried out phenotyping, FB and AC carried out SNP genotyping, data analyses, and manuscript writing. LC advised on linkage mapping and QTL analysis. LC, AI, and AW contributed with experimental design, data analysis and manuscript writing. All authors read, revised and approved the manuscript.

(1)

1

(1)

(2)

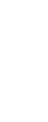




\section{REFERENCES}

622

623

624

625

626

627

628

629

630

631

632

633

634

635

636

637

638

639

640

641

642

643

644

645

646

647

648

649

650

651

652

653

654

655

656

657

658

659

660

Atkinson RG, Sutherland PW, Johnston SL, Gunaseelan K, Hallett IC, Mitra D, Brummell DA, Schroder R, Johnston JW, Schaffer RJ (2012) Down-regulation of POLYGALACTURONASE1 alters firmness, tensile strength and water loss in apple (Malus $\times$ domestica) fruit. BMC Plant Biology 12: 129. https://doi.org/10.1186/14712229-12-129

Alique R, Zamorano JP, Martínez MA, Alonso J (2005) Effect of heat and cold treatments on respiratory metabolism and shelf-life of sweet cherry, type Picota cv 'Ambrunés'. Postharvest Biology and Technology 35(2): 153-165. https://doi.org/10.1016/j.postharvbio.2004.07.003

Bernalte MJ, Hernández MT, Vidal-Aragón MC, Sabio E (1999) Physical, chemical, flavor and sensory characteristics of two sweet cherry varieties grown in 'Valle del Jerte' (Spain). Journal of Food Quality 22(4): 403-416. https://doi.org/10.1111/j.17454557.1999.tb00173.x

Brummell DA, Dal Cin V, Crisosto CH, Labavitch JM (2004) Cell wall metabolism during maturation, ripening and senescence of peach fruit. Journal of Experimental Botany 55: 2029-2039. https://doi.org/10.1093/jxb/erh227

Brummell D, Harpster M (2001) Cell wall metabolism in fruit softening and quality and its manipulation in transgenic plants. Plant Molecular Biology 47: 311-340. https://doi.org/10.1023/A:1010656104304

Cabrera A, Rosyara UR, De Franceschi P, Sebolt A, Sooriyapathirana SS, Dirlewanger E, Quero-Garcia J, Schuster, Iezzoni AF, van der Knaap E (2012) Rosaceae conserved orthologous sequences marker polymorphism in sweet cherry germplasm and construction of a SNP-based map. Tree Genetics and Genomes 8:237-247. https://doi.org/10.1007/s11295-011-0436-9

Cai L, Quero-García J, Barreneche T, Dirlewanger E, Saski C, Iezzoni A (2019) A fruit firmness QTL identified on linkage group 4 in sweet cherry (Prunus avium L.) is associated with domesticated and bred germplasm. Scientific Reports 9: 5008 https://doi.org/10.1038/s41598-019-41484-8

Cai L, Voorrips RE, van de Weg R, Peace C, Iezzoni A (2017) Genetic structure of a QTL hotspot on chromosome 2 in sweet cherry indicates positive selection for favorable haplotypes. Molecular Breeding 37: 85. https://doi.org/10.1007/s11032-017-0699-4

Calle A, Cai L, Iezzoni A, Wünsch A (2018) High-density linkage maps constructed in sweet cherry (Prunus avium L.) using cross- and self-pollinated populations reveal chromosomal homozygosity in inbred families and non-syntenic region with the peach genome. Tree Genetics and Genomes 14: 37. https://doi.org/10.1007/s11295-018-12522

Campoy JA, Le Dantec L, Barreneche T, Dirlewanger E, Quero-García J (2015) New insights into fruit firmness and weight control in sweet cherry. Plant Molecular Biology Reporter 33(4): 783-796. https://doi.org/10.1007/s11105-014-0773-6 

affected by climate change in Prunus avium: flowering date dissection into chilling and heat requirements. New Phytologist 202: 703-715. https://doi.org/10.1111/nph.12658 Johnston JW, Schaffer RJ, Tustin S (2014) Genetic and environmental control of fruit maturation, dry matter and firmness in apple (Malus $x$ domestica Borkh.). Horticulture Research 1: 14046. https://doi.org/10.1038/hortres.2014.46

Chauving M, Withing M, Ross CF (2009) The influence of harvest time on sensory properties and consumer acceptance of sweet cherries. Hort Technol 19: 748-754. https://doi.org/10.21273/HORTSCI.19.4.748

Chavoshi M, Watkins C, Oraguzie B, Zhao Y, Iezzoni A, Oraguzie N (2014) Phenotyping protocol for sweet cherry (Prunus avium L.) to facilitate an understanding of trait inheritance. Journal of American Pomology Society 68(3): 125-134.

Cliff MA, Dever MC, Hall JW, Girard B (1995) Development and evaluation of multiple regression methods for prediction of sweet cherry liking. Food Research International 28: 583-589. https://doi.org/10.1016/0963-9969(95)00041-0

Costa F, Peace CP, Stella S, Serra S, Musacchi S, Bazzani M, Sansavini S, van de Weg E (2010) QTL dynamics for fruit firmness and softening around an ethylene-dependent polygalacturonase gene in apple (Malus $\times$ domestica Borkh.). Journal of Experimental Botany 61(11): 3029-3039. https://doi.org/10.1093/jxb/erq130

Crisosto CH, Crisosto GM, Metheney P (2003) Consumer acceptance of 'Brooks' and 'Bing' cherries is mainly dependent on fruit SSC and visual skin color. Postharvest Biology and Technology 28: 159-167. https://doi.org/10.1016/S0925-5214(02)00173-4

Crisosto CH, Mitchell FG, Johnson S (1995) Factors in fresh market stone fruit quality. Postharvest News Inform 6(2): 17-21.

Da Silva Linge C, Bassi D, Bianco L, Pacheco I, Pirona R, Rossini L (2015) Genetic dissection of fruit weight and size in an F2 peach (Prunus persica (L.) Batsch) progeny. Molecular Breeding 35: 71. https://doi.org/10.1007/s11032-015-0271-z

De Franceschi P, Stegmeir T, Cabrera A, van der Knapp E, Rosyara UR, Sebolt AM,

Dondini L, Dirlewanger E, Quero-García J, Campoy JA, Iezzoni AF (2013) Cell number regulator genes in Prunus provide candidate genes for the control of fruit size in sweet and sour cherry. Molecular Breeding 32: 311-326. https://doi.org/10.1007/s11032-013-9872-6 Schaffer RJ, David KM (2012) A genomics approach to understanding the role of auxin in apple (Malus $x$ domestica) fruit size control. BMC Plant Biology 12:7. https//doi.org/10.1186/1471-2229-12-7

700 Di Guardo M, Micheletti D, Bianco L, Koehorst-Van Putten HJJ, Longhi S, Costa F, 701 Aranzana MJ, Velasco R, Arús P, Troggio M, van de Weg EW (2015) ASSIsT: An 
automatic SNP scoring tool for in- and outbreeding species. Bioinformatics 31: 38733874. https://doi.org/10.1093/bioinformatics/btv446

Dirlewanger E, Claverie J, Iezzoni A, Wünsch A (2009) Sweet and sour cherries: Linkage maps, QTL detection and marker assisted selection. In Genetics and Genomics of Rosaceae, Plant Genetics and Genomics: Crops and Models 6. http://doi.org/10.1007/978-0-387-77491-6_14

Dirlewanger E, Graziano E, Joobeur T, Garriga-Calderé F, Cosson P, Howad W, Arús P (2004) Comparative mapping and marker-assisted selection in Rosaceae fruit crops. Proceedings of the National Academy of Science 101: 9891-9896. https://doi.org/10.1073/pnas.0307937101

Eduardo I, Pacheco I, Chietera G, Bassi D, Pozzi C, Vecchietti A, Rossini L (2011) QTL analysis of fruit quality in two peach intraspecific populations and importance of maturity date pleiotropic effect. Tree Genetics and Genomes 7: 323-335. https://doi.org/10.1007/s11295-010-0334-6

Fogle HW (1961) Inheritance of some fruit and tree characteristics in sweet cherry crosses. Proceedings of the American Society for Horticultural Science 78: 76-85.

Frary A, Nesbitt C, Frary A, Grandillo S, van der Knaap E, Cong B, Liu J, Meller J, Alpert KB, Tanksley S (2000) fw2.2: A quantitative trait locus key to the evolution of tomato fruit size. Science 289: 85-88. https://doi.org/10.1126/science.289.5476.85

Gallardo RK, Li H, McCracken V, Yue C, Luby J, McFerson JR (2015) Market intermediaries' willingness to pay for apple, peach, cherry and strawberry quality attributes. Agribusiness 31: 259-280. https://doi.org/10.1002/agr.21396

Garrido M, Rodríguez AB, Lozano M, Hernández MT, González-Gómez D (2014) Formulation and characterization of a new nutraceutical product based on sweet cherries (Prunus avium L.) grown in the Jerte Valley of Spain. Acta Horticulturae 1020: 149152. https://doi.org/10.17660/ActaHortic.2014.1020.20

Gella R, Fustero R, Rodrigo J (2001) Variedades de cerezo. Servicio de Investigación Agroalimentaria. Diputación General de Aragón.

Gu C, Wang L, Wang W, Zhou H, Ma B, Zheng H, Fang T, Ogutu C, Vilmolmangkang S, Han Y (2016) Copy number variation of a gene cluster encoding endopolygalacturonase mediates flesh texture and stone adhesion in peach. Journal of Experimental Bonaty 67(6): 1993-2005. https://doi.org/10.1093/jxb/erw021

Guajardo V, Solís S, Sagredo B, Gainza F, Muñoz C, Gasic K, Hinrichsen P (2015) Construction of high density sweet cherry (Prunus avium L.) linkage maps using microsatellite markers and SNPs detected by genotyping-by-sequencing (GBS). PLoS One 10:1-17. https://doi.org/10.1371/journal.pone.0127750

Guyer DE, Sinha NK, Chang TS, Cash JN (1993) Physicochemical and sensory characteristics of selected Michigan sweet cherry (Prunus avium L.) cultivars. Journal of Food Quality 16: 355-370. https://doi.org/10.1111/j.1745-4557.1993.tb00121.x 
Herrero M, Rodrigo J, Wünsch A (2017) Flowering, fruit set and development. In Quero-García J, Iezzoni A, Pulawska J, Lang G (eds) Cherries: Botany, Production and Uses. CAB International 2017, Boston, pp 14-35

Illa E, Sargent DJ, Lopez Girona E, Bushakra J, Cestaro A, Crowhurst R, Pindo M, Cabrera A, var der Knaap E, Iezzoni A, Gardiner S, Velasco R, Arús P, Chagné D, Troggio M (2011) Comparative analysis of rosaceous genomes and the reconstruction of a putative ancestral genome for the family. BMC Evolutionary Biology 11:9. https://doi.org/10.1186/1471-2148-11-9.

Jansen RC (1993) Interval mapping of multiple quantitative trait loci. Genetics 135: 205-211.

Jansen RC (1994) Controlling the type I and type II errors in mapping quantitative trait loci. Genetics 138: 871-881.

Jansen RC, Stam P (1994) High resolution of quantitative traits into multiple loci via interval mapping. Genetics 136: 1447-1455.

Klagges C, Campoy JA, Quero-García J, Guzmán A, Mansur L, Gratacós E, Silva H, Rosyara UR, Iezzoni A, Meisel LA, Dirlewanger E (2013) Construction and comparative analyses of highly dense linkage maps of two sweet cherry intra-specific progenies of commercial cultivars. PLoS One 8(1): e54743. https://doi.org/10.1371/journal.pone.0054743

Kosambi DD (1944) The estimation of map distances from recombination values. Annals of Eugenics 12: 172-175. https://doi.org/10.1111/j.1469-1809.1943.tb02321.x

Lamb RC (1953) Notes on the inheritance of some characters in sweet cherry (Prunus avium). Proceedings of the American Society for Horticultural Science 61: 293-298.

Lander ES, Botstein D (1989) Mapping Mendelian factors underlying quantitative traits using RFLP linkage maps. Genetics, 121, pp.185-199.

Lane WD, MacDonald RA (1996) Sweetheart sweet cherry. Canadian Journal of Plant Science 76(1): 161-163.

Leida C, Rios G, Soriano JM, Perez B, Llacer G, Crisosto CH, Badenes ML (2011) Identification and genetic characterization of an ethylene-dependent polygalacturonase from apricot fruit. Postharvest Biology and Technology 62: 26-34. https://doi.org/10.1016/j.postharvbio.2011.04.003

Longhi S, Moretto M, Viola R, Velasco R, Costa F (2012) Comprehensive QTL mapping survey dissects the complex fruit texture physiology in apple (Malus $x$ domestica Borkh.). Jorunal of Experimental Botany 63: 1107-1121 https://doi.org/10.1093/jxb/err326

López-Corrales M, Gragera J, Manzano M (2003) Selección de las variedades de cerezo 'Ambrunés', 'Pico Negro' y 'Pico Colorado' tradicionalmente cultivadas en el Valle del Jerte. Actas de Horticultura 39: 297-299. 

(2014) Preharvest application of oxalic acid increased fruit size, bioactive compounds, and antioxidant capacity in sweet cherry cultivars (Prunus avium L.). Journal of Agricultural and Food Chemistry 62(15): 3432-3437. https://doi.org/10.1021/jf500224g

Martínez-Royo A, Wünsch A (2014) Genetic structure of sweet cherry with the 6K SNP Array v1. 7th International Rosaceae Genomics Conference. Seattle, USA.

Pan Y, Wang Y, McGregor C, Liu S, Luan F, Gao M, Weng Y (2020) Genetic architecture of fruit size and shape variation in cucurbits: a comparative perspective. 3

Peace C, Bassil N, Main D, Ficklin S, Rosyara UR, Stegmeir T, Sebolt A, Gilmore B, Lawley C, Mockler TC, Bryant DW, Wilhelm L, Iezzoni A (2012) Development and evaluation of a genome-wide 6K SNP array for diploid sweet cherry and tetraploid sour cherry. Plos ONE 7(12): e48305. https://doi.org/10.1371/journal.pone.0048305

Piaskowski J, Hardner C, Cai L, Zhao Y, Iezzoni A, Peace C (2018) Genomic heritability estimates in sweet cherry reveal non-additive genetic variance is relevant for industry-prioritized traits. BMC Genetics 19(1): 23. https://doi.org/10.1186/s12863018-0609-8.

Quero-García J, Shuster M, López-Ortega G, Charlot G (2017) Sweet cherry varieties and improvement. In Quero-García J, Iezzoni A, Pulawska J, Lang G (eds) Cherries: Botany, Production and Uses. CAB International 2017, Boston, pp 60-94

Quilot B, Wu BH, Kervella J, Génard M, Foulongne M, Moreau K (2004) QTL analysis of traits in an advanced backcross between Prunus persica genotypes and the wild relative species Prunus davidiana. Theoretical and Applied Genetics 109: 884-897. https://doi.org/10.1007/s00122-004-1703-z

R Core Team (2017) R: a language and environment for statistical computing. R Foundation for Statistical Computing, Vienna. http://www.R-project.org/

Romano GS, Cittadini ED, Pugh B, Schoutten R (2006) Sweet cherry quality in the horticultural production chain. Stewart Postharvest Review 2: 1-9. https://doi.org/10.2212/spr.2006.6.2

Rosyara UR, Bink MCAM, van de Weg E, Zhang G, Wang D, Sebolt A, Dirlewanger E, Quero-García J, Shuster M, Iezzoni AF (2013) Fruit size QTL identification and the prediction of parental QTL genotypes and breeding values in multiple pedigreed populations in sweet cherry. Molecular Breeding 32: 875-887. https://doi.org/10.1007/s11032-013-9916-y

Serradilla M, Hernández A, Ruíz-Moyano S, Benito MJ, López-Corrales M, Córdoba MDG (2013) Authentication of 'Cereza del Jerte' cherry cultivars using real time PCR. Food Control 30(2): 679-685. https://doi.org/10.1016/j.foodcont.2012.08.018

Serradilla MJ, López-Corrales M, Wünsch A (2014) Molecular discrimination of 'Picota' sweet cherries using fruit tissue. Acta Horticulturae 1020: 75-78. https://doi.org/10.17660/ActaHortic.2014.1020.8 

Gómez D (2011) Physicochemical and bioactive properties evolution during ripening of 'Ambrunés' sweet cherry cultivar. LTW-Food Science and Technology 44(1): 199-205. https://doi.org/10.1016/j.lwt.2010.05.036

827 Serradilla MJ, Martín A, Aranda E, Hernández A, Benito MJ, López-Corrales M, 828 Cordoba MG (2008) Authentication of 'Cereza del Jerte' sweet cherry varieties by free 829 zone capillaray electrophoresis (FZCE). Food Chemistry 111(2): 457-461. https://doi.org/10.1016/j.foodchem.2008.03.084

Serradilla MJ, Martín A, Hernández A, López-Corrales M, Lozano AM, Córdoba MG (2010) Effect of the comercial ripening stage and postharvest storage on microbial and aroma changes of 'Ambrúnes' sweet cherry. Journal of Agricultural and Food Chemistry 58(16): 9157-9163. https://doi.org/10.1021/jf102004v

Serradilla MJ, Martín A, Ruíz-Moyano S, Hernández A, López-Corrales M, Córdoba MDG (2012) Physicochemical and sensorial characterisation of four sweet cherry cultivars grown in Jerte Valley (Spain). Food Chemistry 133(4): 1551-1559. https://doi.org/10.1016/j.foodchem.2012.02.048

Serradilla, M.J. et al., (2016). Composition of the Cherry (Prunus avium L. and Prunus cerasus L.; Rosaceae). In M. S. J. Simmonds \& V. R. Preedy, eds. Nutritional Compositions of Fruit Cultivars. Academic Press, pp 127-147.

Serrano M, Guillén F, Martínez-Romero D, Castillo S, Valero, D (2005) Chemical constituents and antioxidant of sweet cherry at different ripening stages. Journal Agricultural and Food Chemistry 53: 2741-2745. https://doi.org/10.1021/jf0479160

Tavassolian I, Rabiei G, Gregory D, Mnejja M, Wirthensohn MG, Hunt PW, Gibson JP, Ford CM, Sedgley M, Wu SB (2010) Construction of an almond linkage map in an Australian population Nonpareil $\times$ Lauranne. BMC Genomics 11: 551. https://doi.org/10.1186/1471-2164-11-551

van Ooijen JW (1992) Accuracy of mapping quantitative trait loci in autogamous species. Theoretical and Applied Genetics 84: 803-811. https://doi.org/10.1007/BF00227388.

van Ooijen JW (2006) JoinMap® 4, Software for the calculation of genetic linkage maps in experimental populations, Wageningen, Netherlands: Kyazma B.V.

van Ooijen JW (2009) MapQTL ${ }^{\circledR}$ 6, software for mapping of quantitative trait in experimental populations of diploid species. Wageningen, Netherlands: Kyazma B.V.

Verde I, Jenkins J, Dondini L, Micali S, Pagliarani G, Vendramin E, Paris R, Aramini V, Gazza L, Rossini L, Bassi D, Troggio M, Shu S, Grimwood J, Tartarini S, Dettori MT, Schmutz J (2017) The Peach v2.0 release: high-resolution linkage mapping and deep resequencing improve chromosome-scale assembly and contiguity. BMC Genomics 18: 1-18. https://doi.org/10.1186/s12864-017-3606-9

861 Voorrips RE (2002) MapChart: Software for the graphical presentation of linkage maps 862 and QTLs. The Journal of Heredity 93(1): 77-78. https://doi.org/10.1093/jhered/93.1.77 
863 Wang D, Karle R, Iezzoni, AF (2000) QTL analysis of flower and fruit traits in sour 864 cherry. Theoretical and Applied Genetics 100(3-4): 535-544. 865 https://doi.org/10.1007/s001220050070

866 Whiting MD, Ophardt D, McFerson JR (2006) Chemical blossom thinners vary in their 867 effect on sweet cherry fruit set, yield, fruit quality, and crop value. Hort Technol 16: 868 66-70. https://doi.org/10.21273/HORTTECH.16.1.0066

869 Wünsch A, Hormaza JI (2002) Molecular characterization of sweet cherry (Prunus 870 avium L.) cultivars using peach (Prunus persica L. Batsch.) SSR sequences. Heredity 871 89(1): 56-63. https://doi.org/10.1038/sj.hdy.6800101

872 Zeballos JL, Abidi W, Giménez R, Monforte AJ, Moreno MA, Gogorcena Y (2016) 873 Mapping QTLs associated with fruit quality traits in peach [Prunus persica (L.) Batsch] 874 using SNP maps. Tree Genetics and Genomes 12: 37. https://doi.org/10.1007/s11295875 016-0996-9

876 Zhang G, Sebolt AM, Sooriyapathirana SS, Wang D, Bink MCAM, Olmstead JW, 877 Iezzoni A (2010) Fruit size QTL analysis of an F1 population derived from a cross 878 between a domesticated sweet cherry cultivar and a wild forest sweet cherry. Tree 879 Genetics and Genomes 6(1): 25-36. https://doi.org/10.1007/s11295-009-0225-X

880 Zoffoli JP, Toivonen P, Wang Y (2017) Postharvest Biology and Handling for Fresh 881 Markets. In Quero-García J, Iezzoni A, Pulawska J, Lang G (eds) Cherries: Botany, 882 Production and Uses. CAB International 2017, Boston, pp 460-484 
Table 1 Significance, genetic interval, QTL peak and physical position of QTLs identified for both years for weight, diameter and firmness in A $\times$ S population.

\begin{tabular}{|c|c|c|c|c|c|c|c|c|c|c|c|c|}
\hline \multirow[b]{2}{*}{ Trait } & \multirow[b]{2}{*}{$\begin{array}{l}\text { Parental } \\
\text { cultivar }\end{array}$} & \multirow[b]{2}{*}{ Year } & \multirow[b]{2}{*}{ QTL name } & \multirow[b]{2}{*}{ LG } & \multirow{2}{*}{$\begin{array}{c}\text { QTL } \\
\text { interval } \\
(\mathbf{c M})\end{array}$} & \multirow[b]{2}{*}{$\begin{array}{l}\text { Physical } \\
\text { position* }\end{array}$} & \multicolumn{5}{|c|}{ QTL peak } & \multirow{2}{*}{$\begin{array}{c}\text { QTL } \\
\text { previously } \\
\text { described } \\
\text { (Reference) }\end{array}$} \\
\hline & & & & & & & SNP & LOD & Variance & $\mathbf{P V E}^{+}$ & $\begin{array}{c}\text { Additive } \\
\text { effect }\end{array}$ & \\
\hline \multirow[t]{3}{*}{ Weight } & 'Ambrunés' & Y1 & $q P-F W 1.1^{m}$ & 1 & $104.76-120.38$ & $28.65-30-92$ & ss490546431 & 3.20 & 1.04 & 15.4 & 0.43 & $F W_{-} G l^{(1)}$ \\
\hline & & Y2 & $q P-F W 1.1^{m}$ & 1 & $101.76-129.84$ & $27.14-33.24$ & ss490547198 & 3.87 & 1.57 & 17.4 & 0.63 & $f w 1.1^{(2)}$ \\
\hline & 'Sweetheart' & Y2 & $q P-F W 3.1$ & 3 & $21.10-25.70$ & 4.11-4.54 & ss490552023 & 2.77 & 1.55 & 11.9 & 0.59 & $(1,2)$ \\
\hline \multirow[t]{4}{*}{ Diameter } & 'Ambrunés' & $\mathrm{Y} 1$ & $q P-F D 1.1^{m}$ & 1 & $70.07-79.16$ & $19.01-23.52$ & ss490546727 & 2.69 & 2.63 & 12.9 & 0.62 & $f w 1.1^{(2)}$ \\
\hline & & Y2 & $q P-F D 1.1^{m}$ & 1 & $52.27-71.02$ & 10.69-19.64 & ss490546442 & 2.36 & 4.02 & 11.0 & 0.71 & \\
\hline & & Y1 & $q P-F D 1.2^{m}$ & 1 & $100.76-118.87$ & $26.47-30.69$ & ss490547198 & 2.25 & 2.69 & 10.9 & 0.65 & $F W \_G l^{(1)}$ \\
\hline & & $\mathrm{Y} 2$ & $q P-F D 1.2^{m}$ & 1 & $102.77-118.12$ & $27.68-30.60$ & ss490547198 & 2.33 & 4.02 & 10.9 & 0.80 & $f w 1.1^{(2)}$ \\
\hline \multirow[t]{5}{*}{ Firmness } & 'Ambrunés' & Y1 & $q P-F F 1.1^{m}$ & 1 & $60.30-76.29$ & $12.61-23.08$ & ss490546554 & 4.08 & 0.45 & 18.8 & 0.33 & $f f 1.1^{(2)}$ \\
\hline & & $\mathrm{Y} 2$ & $q P-F F 1.1^{m}$ & 1 & $61.34-74.28$ & $13.41-22.97$ & ss490546599 & 3.31 & 0.23 & 12.7 & 0.21 & (3) \\
\hline & & $\mathrm{Y} 2$ & $q P$-FF6.1 & 6 & $38.96-71.07$ & $7.71-19.87$ & ss490555470 & 3.19 & 0.27 & 14.3 & 0.22 & $f f 6.1^{(2)(3)}$ \\
\hline & 'Sweetheart' & Y1 & $q P-F F 1.2^{m}$ & 1 & $16.84-30.76$ & $15.25-24.18$ & ss490546651 & 5.00 & 0.43 & 22.5 & -0.69 & $f f 1.1^{(2)}$ \\
\hline & & Y2 & $q P-F F 1.2^{m}$ & 1 & $19.13-28.76$ & $17.58-23.51$ & ss490559249 & 2.84 & 0.28 & 12.9 & -0.20 & \\
\hline
\end{tabular}

${ }^{*}$ Physical position (Mbps) of SNP markers in peach genome v2.0.a1 (Verde et al. 2017). ${ }^{+}$PVE: Proportion of variance explained. References: ${ }^{1}$ Rosyara et al. 2013, ${ }^{2}$ Campoy et al. $2015,{ }^{3}$ Cai et al. 2019. 
Table 2 Fruit weight, diameter and firmness mean phenotypic values recorded in individuals for detected QTLs (diplotypes). Haplotypes highlighted in bold are associated with the increase in phenotype values.

\begin{tabular}{|c|c|c|c|c|c|c|c|c|}
\hline \multirow[t]{2}{*}{ Trait } & \multirow[t]{2}{*}{ Parent } & \multirow[t]{2}{*}{ LG } & \multirow[t]{2}{*}{ QTL } & \multirow[t]{2}{*}{ Haplotypes } & \multicolumn{2}{|c|}{ Y1 } & \multicolumn{2}{|l|}{ Y2 } \\
\hline & & & & & Mean & $\mathbf{N}$ & Mean & $\mathbf{N}$ \\
\hline \multirow[t]{4}{*}{ Weight } & 'Ambrunés' & 1 & $q P-F W 1.1^{m}$ & FW1.1_H1 / FW1.1_H1 & $5.2 \pm 0.9^{\mathrm{a}}$ & 46 & $5.5 \pm 1.2^{\mathrm{a}}$ & 56 \\
\hline & & & & FW1.1_H2 / FW1.1_H1 & $6.1 \pm 1.1^{b}$ & 43 & $6.6 \pm 1.5^{b}$ & 33 \\
\hline & 'Sweetheart' & 3 & $q P-F W 3.1$ & FW3.1_H1 / FW3.1_H2 & $5.7 \pm 1.1$ & 39 & $6.3 \pm 1.4^{\mathrm{a}}$ & 43 \\
\hline & & & & FW3.1_H1 / FW3.1_H3 & $5.6 \pm 1.1$ & 48 & $5.6 \pm 1.3^{b}$ & 48 \\
\hline \multirow[t]{4}{*}{ Diameter } & 'Ambrunés' & 1 & $q P-F D 1.1^{m}$ & FD1.1_H1/FD1.1_H3 & $21.0 \pm 1.5^{\mathrm{a}}$ & 32 & $20.9 \pm 2.1^{\mathrm{a}}$ & 42 \\
\hline & & & & FD1.1_H2 / FD1.1_H3 & $22.2 \pm 2.0^{b}$ & 32 & $22.8 \pm 2.3^{b}$ & 27 \\
\hline & & 1 & $q P-F D 1.2^{m}$ & FD1.2_H1 / FD1.2_H3 & $21.1 \pm 1.6^{\mathrm{a}}$ & 46 & $21.1 \pm 2.0^{\mathrm{a}}$ & 56 \\
\hline & & & & FD1.2_H2 / FD1.2_H3 & $22.1 \pm 1.7^{b}$ & 44 & $22.5 \pm 2.2^{b}$ & 34 \\
\hline \multirow[t]{6}{*}{ Firmness } & 'Ambrunés’ / & 1 & $q P-F F 1.1^{m} /$ & FF1.1_H1 /FF1.2_H2 & $1.4 \pm 0.4^{\mathrm{a}}$ & 14 & $1.4 \pm 0.4^{\mathrm{a}}$ & 18 \\
\hline & 'Sweetheart' & & $q P-F F 1.2^{m}$ & $F F 1.1 \_H 1 / F F 1.2 \_H 3$ & $1.4 \pm 0.4^{\mathrm{a}}$ & 19 & $1.3 \pm 0.42^{\mathrm{a}}$ & 24 \\
\hline & & & & FF1.1_H2 / FF1.2_H2 & $2.2 \pm 0.9^{b}$ & 23 & $2.0 \pm 0.7^{b}$ & 22 \\
\hline & & & & $F F 1.1 \_H 2 / F F 1.2 \_H 3$ & $1.7 \pm 0.6^{\mathrm{a}}$ & 21 & $1.4 \pm 0.4^{\mathrm{a}}$ & 19 \\
\hline & 'Ambrunés' & 6 & $q P-F F 6.1$ & FF6.1_H1 / qP-FF6.1_H3 & $1.9 \pm 0.8^{a}$ & 31 & $1.8 \pm 0.6^{a}$ & 36 \\
\hline & & & & FF6.1_H2 / qP-FF6.1_H3 & $1.5 \pm 0.6^{b}$ & 47 & $1.4 \pm 0.4^{b}$ & 48 \\
\hline
\end{tabular}

Different letters indicate significant differences between means at $\mathrm{P}<0.05$ 
Figure 1 Frequency distribution of fruit weight, diameter and firmness for $A \times S$ population in two years (Y1 and Y2). Grey and black bars indicate phenotypic values for 'Ambrunés' and 'Sweetheart', respectively. 
Y1
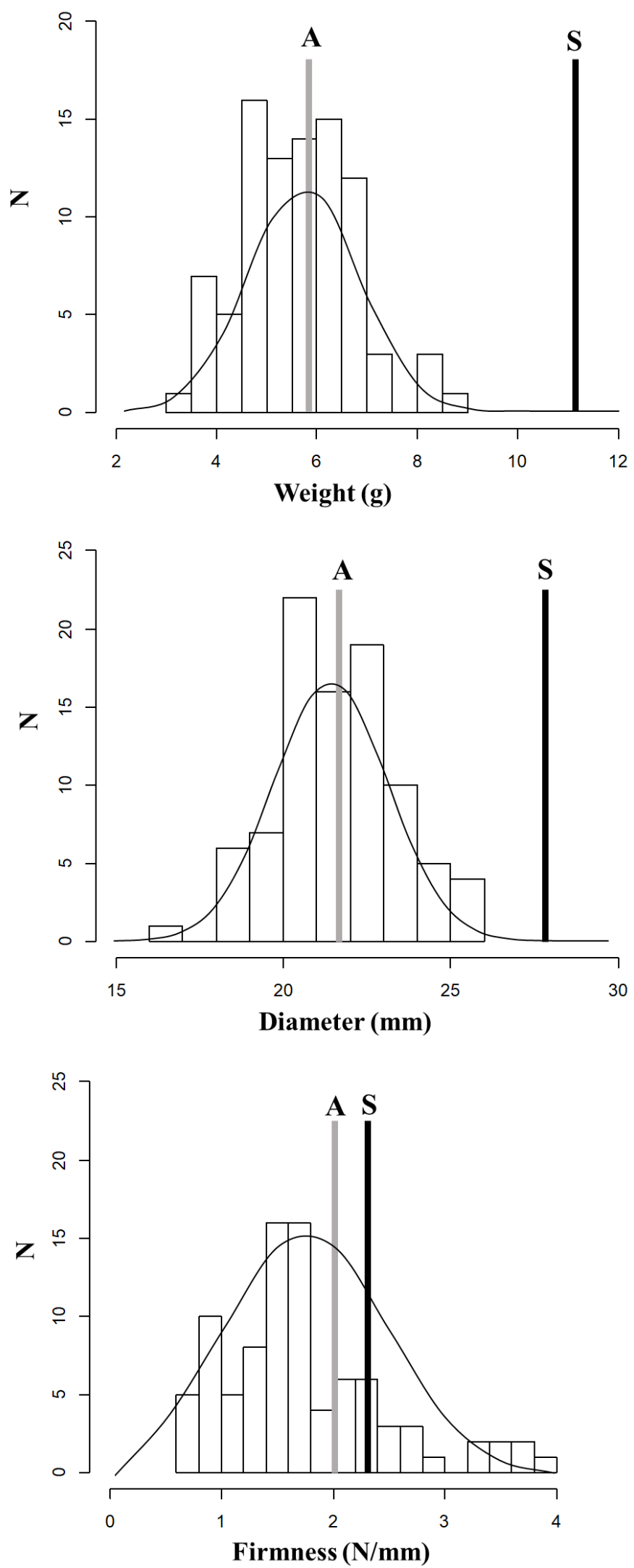

Y2
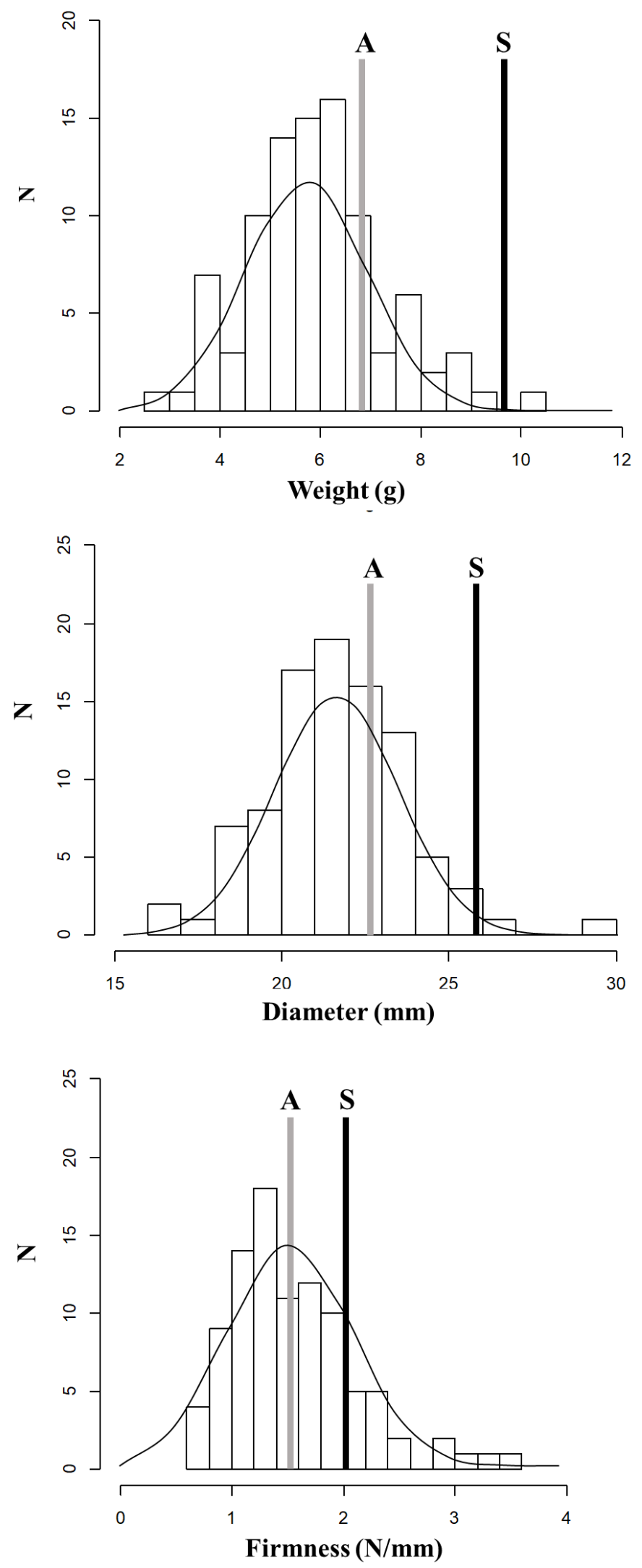
Figure 2 Pairwise correlations for fruit weight, diameter and firmness in two years (Y1 and Y2). Pearson coefficient ( $\mathrm{r}$ ) and $\mathrm{P}$ value (p) are presented for each plot. Asterisk indicates significant correlation at $\mathrm{p}<0.01$. 


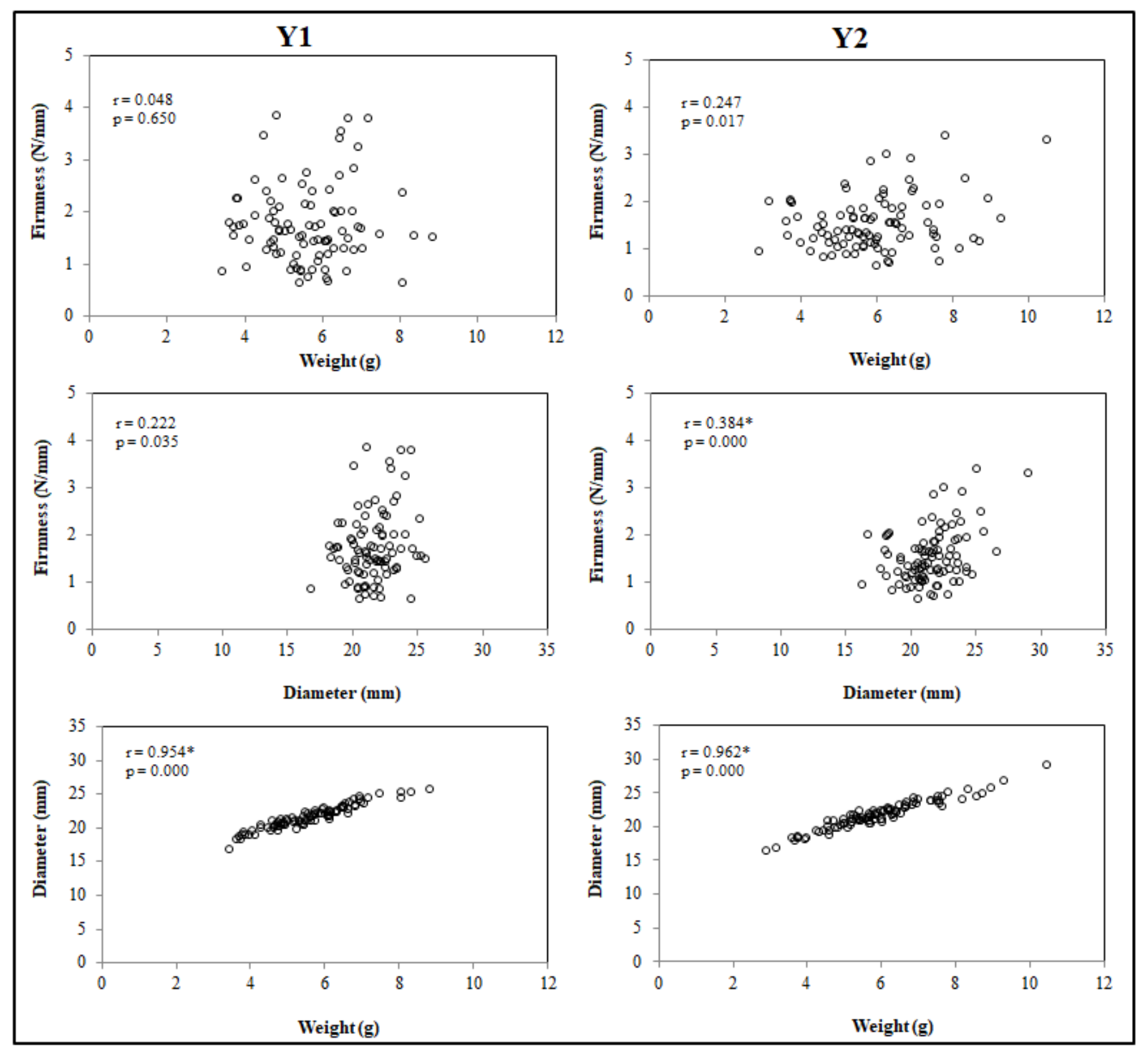


Figure 3 Graphical representation of detected QTLs for fruit weight (black), diameter (blue) and firmness (red) on 'Ambrunés' and 'Sweetheart' parental maps. 
cM

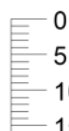

15

長 20

長 30

产 35

衰 40

政 40

卧 55

产 60

E 65

臨 70

衰 75

85

90

長 95

产 105

E 110

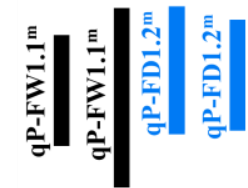

LG1 A LG1 A×S LG1S

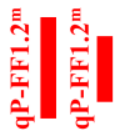

LG3 S

LG6 A

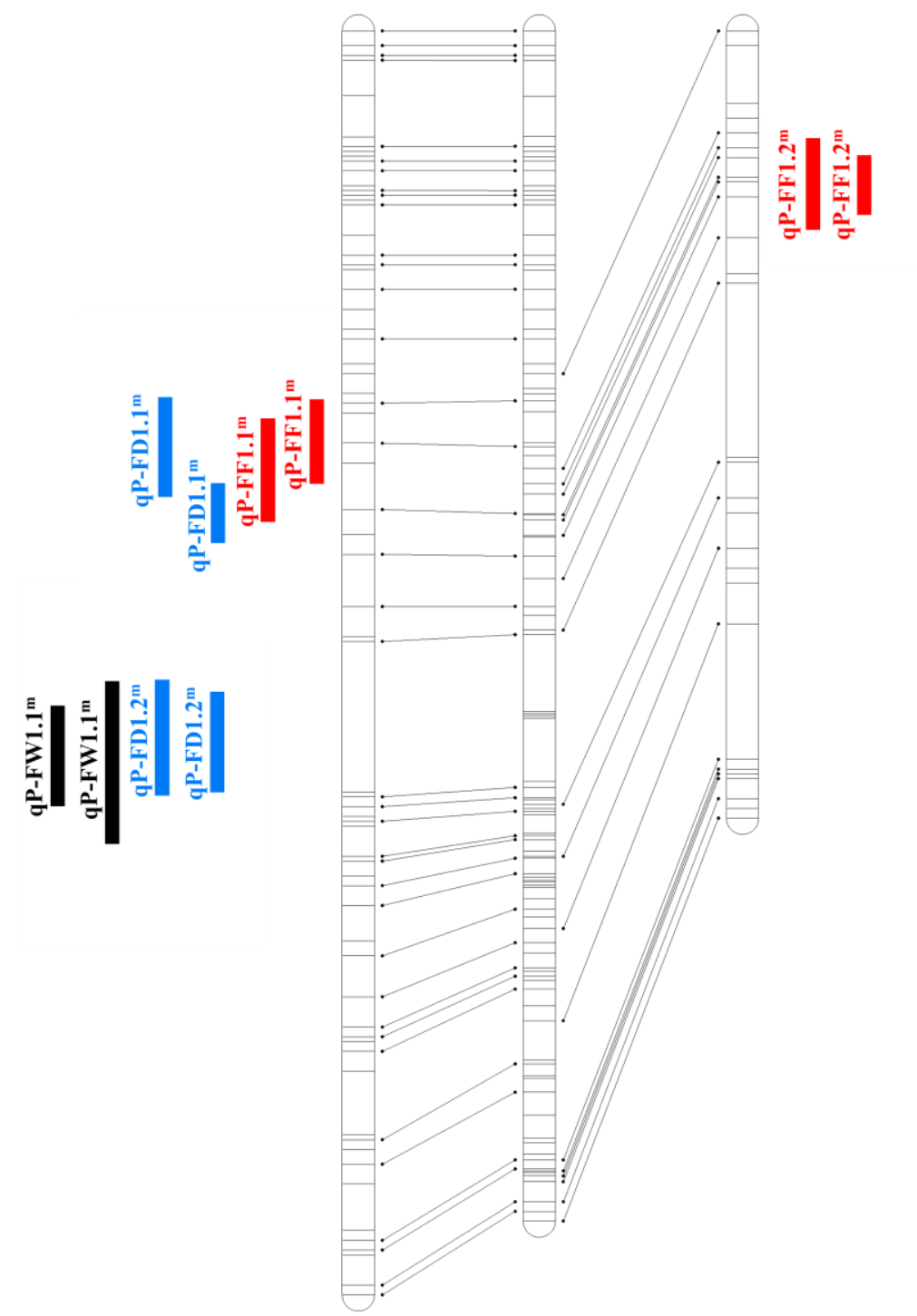

畒

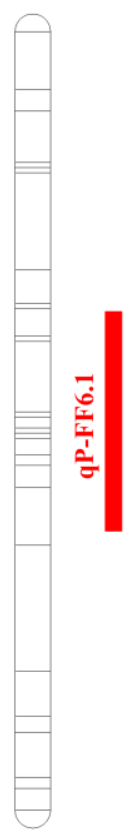


Online Resource 1 Summary of phenotypic data for mean fruit weight, diameter and firmness for an A×S population in year 2015 and 2016 (Y1 and Y2).

\begin{tabular}{clcccccc}
\cline { 3 - 8 } & \multicolumn{2}{c}{ Weight $(\mathbf{g})$} & \multicolumn{2}{c}{ Diameter $(\mathbf{m m})$} & \multicolumn{2}{c}{$\begin{array}{c}\text { Firmness } \\
(\mathbf{N} / \mathbf{m m})\end{array}$} \\
\cline { 3 - 8 } & $\mathbf{Y 1}^{\mathbf{a}}$ & $\mathbf{Y 2}^{\mathbf{b}}$ & $\mathbf{Y 1}^{\mathbf{a}}$ & $\mathbf{Y 2}^{\mathbf{b}}$ & Y1 $^{\mathbf{a}}$ & $\mathbf{Y 2}^{\mathbf{b}}$ \\
\hline 'Ambrunés' & 5.8 & 6.8 & 21.6 & 22.8 & 2.0 & 1.5 \\
'Sweetheart' & & 11.3 & 9.5 & 27.7 & 25.8 & 2.2 & 2.1 \\
\hline $\mathbf{A} \times \mathbf{S}$ & mean & 5.6 & 5.9 & 21.6 & 21.6 & 1.7 & 1.5 \\
& s.d. & 1.1 & 1.3 & 1.7 & 2.1 & 0.7 & 0.6 \\
& Min. & 3.4 & 2.9 & 16.8 & 16.4 & 0.6 & 0.7 \\
& Max. & 11.3 & 13.1 & 25.7 & 29.1 & 3.8 & 3.4 \\
& $H^{2}$ & 0.63 & & 0.66 & & 0.75 & \\
\hline
\end{tabular}

${ }^{\mathrm{a}}$ Measures performed on 10 fruits per individual in year $1 ;{ }^{\mathrm{b}}$ Measures performed on 25 fruits per individual in year 2. s.d.: standard deviation; $H^{2}$ : Broad-sense heritability. 
Online Resource 2 Number of SNP markers, genetic length, average marker distance and maximum gap for the 'Ambrunés' $(A)$, 'Sweetheart' $(S)$ and consensus $(A \times S)$ maps. (cM; centiMorgan).

\begin{tabular}{lcccccccccc} 
& $\begin{array}{c}\text { Genetic } \\
\text { map }\end{array}$ & LG1 & LG2 & LG3 & LG4 & LG5 & LG6 & LG7 & LG8 & Total \\
\hline umber of & $\mathbf{A}$ & 108 & 27 & 63 & 46 & 32 & 41 & 83 & 63 & $\mathbf{4 6 3}$ \\
markers & $\mathbf{S}$ & 47 & 53 & 12 & 14 & 42 & 27 & 12 & 47 & $\mathbf{2 5 4}$ \\
& $\mathbf{A} \times \mathbf{S}$ & 185 & 93 & 85 & 62 & 84 & 91 & 99 & 121 & $\mathbf{8 2 0}$ \\
\hline \multirow{2}{*}{ Genetic } & $\mathbf{A}$ & 196.1 & 105 & 117.3 & 93.2 & 64 & 109.5 & 97.9 & 84.8 & $\mathbf{8 6 7 . 8}$ \\
length $(\mathbf{c M})$ & $\mathbf{S}$ & 122.2 & 90.1 & 25.7 & 17.9 & 61.6 & 84.9 & 63.9 & 62.8 & $\mathbf{5 2 9 . 1}$ \\
& $\mathbf{A} \times \mathbf{S}$ & 184.7 & 98.6 & 111.1 & 92.9 & 76.2 & 95.7 & 91.6 & 76.8 & $\mathbf{8 2 7 . 6}$ \\
\hline Average & $\mathbf{A}$ & 1.8 & 4 & 1.9 & 2.1 & 2.1 & 2.7 & 1.2 & 1.4 & $\mathbf{2 . 1}$ \\
marker & $\mathbf{S}$ & 2.2 & 1.7 & 2.3 & 1.5 & 1.5 & 3.2 & 5.7 & 1.4 & $\mathbf{2 . 4}$ \\
distance $(\mathbf{c M})$ & $\mathbf{A} \times \mathbf{S}$ & 1 & 1.1 & 1.3 & 1.5 & 0.9 & 1.1 & 0.9 & 0.6 & $\mathbf{1}$ \\
\hline \multirow{2}{*}{ Maximum } & $\mathbf{A}$ & 23.4 & 33.9 & 28.4 & 31.1 & 9 & 17.7 & 12.7 & 19.9 & $\mathbf{3 3 . 9}$ \\
gap (cM) & $\mathbf{S}$ & 31.1 & 8.1 & 7.2 & 7.2 & 15.6 & 31.1 & 28.4 & 9.9 & $\mathbf{3 1 . 1}$ \\
\hline
\end{tabular}


Online Resource 3 Alignment of linkage groups for 'Ambrunés', 'Sweetheart' and the 'Ambrunés' $\times$ 'Sweetheart' consensus maps. Asterisks indicate deviation from expected Mendelian segregation $(* \mathrm{p}<0.1 ; * * \mathrm{p}<0.05$; *** $\mathrm{p}<0.01$; **** $\mathrm{p}<0.005$; ***** $\mathrm{p}<0.001$; $* * * * * * \mathrm{p}<0.0005)$ 
Online Resource 4 Genetic position of RosBREED cherry 6K SNP Array v1 SNPs mapped in 'Ambrunés', 'Sweetheart' and consensus map $(\mathrm{A} \times \mathrm{S})$. 
Online Resource 5 SNP markers that were placed on the 'Ambrunés', 'Sweetheart' and $\mathrm{A} \times \mathrm{S}$ genetic maps in different linkage groups compared to their physical map locations on the peach genome v2.0.a1.

\begin{tabular}{cccccc}
\hline $\begin{array}{c}\text { Physical position Peach } \\
\text { Genome v2.0.a1 }\end{array}$ & \multicolumn{5}{c}{ Genetic position (cM) } \\
\hline Chr & Position & LG & 'Ambrunés' & 'Sweetheart' & A×S \\
\hline 1 & 7885062 & 8 & 54.74 & - & 52.09 \\
2 & 21123343 & 1 & - & 37.64 & 90.73 \\
2 & 1599643 & 8 & - & 13.66 & 17.89 \\
3 & 8158606 & 6 & 64.12 & - & 59.56 \\
3 & 1870601 & 8 & - & 47.18 & 51.52 \\
4 & 19842873 & 7 & 3.83 & - & 3.83 \\
4 & 21492752 & 8 & - & 26.29 & 30.68 \\
6 & 6504161 & 1 & - & 18.13 & 70.34 \\
8 & 10717040 & 2 & - & 22.77 & 26.01 \\
\hline
\end{tabular}


Online Resource 6 Parental haplotypes identified in fruit weight, diameter and firmness QTLs (Table 2). SNP physical positions (bp) are estimated from the Peach Genome v2.0.a1 (Verde et al. 2017). The same haplotypes were identified for the overlapping QTLs $q P-F W 1.1^{m}$ and $q P-F D 1.2^{m}$.

\begin{tabular}{|c|c|c|c|c|c|c|}
\hline \multicolumn{7}{|c|}{$q P-F W 1.1^{m}$} \\
\hline & & & \multicolumn{2}{|c|}{ 'Ambrunés' } & \multicolumn{2}{|c|}{ 'Sweetheart' } \\
\hline SNP & Chr & bp & FW1.1_H1 & $F W 1.1 \_H 2$ & $F W 1.1 \_H 1$ & FW1.1_H1 \\
\hline ss490547198 & 1 & 30690215 & B & A & B & B \\
\hline ss 490546431 & 1 & 30764281 & A & B & A & A \\
\hline
\end{tabular}

\begin{tabular}{|c|c|c|c|c|c|c|}
\hline \multicolumn{7}{|c|}{$q P-F W 3.1$} \\
\hline \multirow[b]{2}{*}{ SNP } & \multirow[b]{2}{*}{ Chr } & \multirow[b]{2}{*}{ bp } & \multicolumn{2}{|c|}{ 'Ambrunés' } & \multicolumn{2}{|c|}{ 'Sweetheart' } \\
\hline & & & FW3.1_H1 & FW3.1_H1 & $F W 3.1 \_H 2$ & $F W 3.1 \_H 3$ \\
\hline ss 490552023 & 3 & 23623922 & B & B & A & B \\
\hline ss 490552038 & 3 & 23855261 & A & A & A & B \\
\hline ss490552061 & 3 & 24361309 & B & B & A & B \\
\hline ss 490552064 & 3 & 24407942 & B & B & A & B \\
\hline
\end{tabular}

\begin{tabular}{|c|c|c|c|c|c|c|}
\hline \multicolumn{7}{|c|}{$q P-F D 1.1^{m}$} \\
\hline \multirow[b]{2}{*}{ SNP } & \multirow[b]{2}{*}{ Chr } & \multirow[b]{2}{*}{ bp } & \multicolumn{2}{|c|}{ 'Ambrunés' } & \multicolumn{2}{|c|}{ 'Sweetheart' } \\
\hline & & & FD1.1_H1 & $F D 1.1 \_H 2$ & FD1.1_H3 & FD1.1_H \\
\hline ss490546442 & 1 & 11556023 & B & $\mathrm{A}$ & $\mathrm{A}$ & $\mathrm{A}$ \\
\hline ss490546096 & 1 & 12618203 & A & B & A & A \\
\hline ss490546554 & 1 & 14735491 & B & A & A & A \\
\hline ss490546591 & 1 & 15601111 & B & A & B & B \\
\hline ss490546599 & 1 & 15753605 & B & A & A & A \\
\hline ss490546727 & 1 & 22976838 & B & A & A & A \\
\hline ss490546746 & 1 & 23079385 & B & A & A & A \\
\hline ss 490546762 & 1 & 23528689 & A & B & B & B \\
\hline
\end{tabular}

\begin{tabular}{ccccccc}
\hline \multicolumn{7}{c}{$\boldsymbol{q P}$-FD1.2 } \\
\hline 'Ambrunés' & \multicolumn{2}{c}{ 'Sweetheart' } \\
\hline SNP & Chr & bp & FD1.2_H1 & FD1.2_H2 & FD1.2_H1 & FD1.2_H1 \\
\hline ss490547198 & 1 & 30690215 & B & A & B & B \\
ss490546431 & 1 & 30764281 & A & B & A & A \\
\hline
\end{tabular}

\begin{tabular}{ccccccc}
\hline \multicolumn{7}{c}{$\boldsymbol{q P} \boldsymbol{P}$-FF1.1 } \\
\hline & & \multicolumn{2}{c}{ 'Ambrunés' } & \multicolumn{2}{c}{ 'Sweetheart' } \\
\hline SNP & Chr & bp & FF1.1_H1 & FF1.1_H2 & FF1.1_H3 & FF1.1_H3 \\
\hline ss490546096 & 1 & 12618203 & A & B & A & A \\
ss490546554 & 1 & 14735491 & B & A & A & A \\
ss490546591 & 1 & 15601111 & B & A & B & B \\
ss490546599 & 1 & 15753605 & B & A & A & A \\
\hline
\end{tabular}




\begin{tabular}{|c|c|c|c|c|c|c|}
\hline \multicolumn{7}{|c|}{ qP-FF $1.2^{m}$} \\
\hline \multirow[b]{2}{*}{ SNP } & \multirow[b]{2}{*}{ Chr } & \multirow[b]{2}{*}{ bp } & \multicolumn{2}{|c|}{ 'Ambrunés' } & \multicolumn{2}{|c|}{ 'Sweetheart' } \\
\hline & & & FF1.2 H1 & FF1.2 H1 & FF1.2 $\mathrm{H} 2$ & FF1.2 H3 \\
\hline ss490546611 & 1 & 16036105 & B & B & A & B \\
\hline ss490558902 & 1 & 17583149 & A & A & B & A \\
\hline ss490546643 & 1 & 17586989 & A & A & B & A \\
\hline ss490546651 & 1 & 18545593 & B & B & B & A \\
\hline ss490546675 & 1 & 20811017 & A & A & A & B \\
\hline ss490546679 & 1 & 20973954 & B & B & B & A \\
\hline
\end{tabular}

\begin{tabular}{|c|c|c|c|c|c|c|}
\hline \multicolumn{7}{|c|}{ qP-FF6.1 } \\
\hline \multirow[b]{2}{*}{ SNP } & \multirow[b]{2}{*}{ Chr } & \multirow[b]{2}{*}{ bp } & \multicolumn{2}{|c|}{ 'Ambrunés' } & \multicolumn{2}{|c|}{ 'Sweetheart' } \\
\hline & & & FF6.1_H1 & FF6.1_H2 & FF6.1_H3 & FF6.1_H3 \\
\hline ss490555481 & 6 & 8706130 & B & $\mathrm{A}$ & B & B \\
\hline ss490555577 & 6 & 11143147 & B & A & B & B \\
\hline ss490555606 & 6 & 11924877 & B & A & B & B \\
\hline ss490559341 & 6 & 14676913 & B & A & A & A \\
\hline ss490559338 & 6 & 14677020 & B & A & A & A \\
\hline ss490555714 & 6 & 17494929 & A & B & B & B \\
\hline
\end{tabular}


Online Resource 7 Mean fruit firmness values of $A \times S$ progeny individuals with different 'Ambrunés' haplotypes combinations at detected firmness QTLs $\left(q P-F F 1.1^{m}\right.$ and $q P$ FF6.1).

\begin{tabular}{|c|c|c|c|c|c|}
\hline \multirow[t]{2}{*}{$q P-F F 1.1^{m}$} & \multirow[t]{2}{*}{ qP-FF6.1 } & \multicolumn{2}{|c|}{ Y1 } & \multicolumn{2}{|c|}{ Y2 } \\
\hline & & Mean & $\mathbf{N}$ & Mean & $\mathbf{N}$ \\
\hline Fir1.1_H1 & Fir6.1_H1 & $1.6 \pm 0.4^{\mathrm{a}}$ & 11 & $1.5 \pm 0.4^{\mathrm{a}}$ & 16 \\
\hline Fir1.1_H1 & Fir6.1_H2 & $1.3 \pm 0.4^{\mathrm{a}}$ & 22 & $1.3 \pm 0.4^{\mathrm{a}}$ & 24 \\
\hline Fir1.1_H2 & Fir6.1_H1 & $2.2 \pm 0.9^{c}$ & 16 & $2.0 \pm 0.7^{b}$ & 15 \\
\hline Fir1.1_H2 & Fir6.1_H2 & $1.8 \pm 0.7^{\mathrm{ab}}$ & 22 & $1.5 \pm 0.5^{\mathrm{a}}$ & 22 \\
\hline
\end{tabular}

Different letters indicate significant differences between classes $(\mathrm{P}<0.05)$. 
Online Resource 8 Phenotype value of 'Ambrunés' LG1 QTLs $\left(q P-F F 1.1^{m}, q P-F D 1.1^{m}, q P-F D 1.2^{m}\right.$ and $\left.q P-F W 1.1^{m}\right)$ in parental cultivars, progeny, and selected individuals of breeding interest.

\begin{tabular}{|c|c|c|c|c|c|c|c|c|c|c|}
\hline & \multirow{2}{*}{$q P-F F 1.1^{m}$} & \multirow{2}{*}{$q P-F D 1.1^{m}$} & \multirow{2}{*}{$q P-F D 1.2^{m}$} & \multirow{2}{*}{$q P-F W 1.1^{m}$} & \multicolumn{2}{|c|}{ Firmness } & \multicolumn{2}{|c|}{ Diameter } & \multicolumn{2}{|c|}{ Weight } \\
\hline & & & & & Y1 & Y2 & Y1 & $\mathbf{Y 2}$ & Y1 & Y2 \\
\hline ‘Ambrunés’ & $H 1 / H 2$ & $H 1 / H 2$ & $H 1 / H 2$ & $H 1 / H 2$ & 2 & 1.5 & 21.6 & 22.8 & 5.8 & 6.8 \\
\hline 'Sweetheart' & $H 3 / H 3$ & $H 3 / H 3$ & $H 3 / H 3$ & $H 1 / H 1$ & 2.2 & 2.1 & 27.7 & 25.8 & 11.3 & 9.5 \\
\hline Progeny mean & - & - & - & - & 1.7 & 1.5 & 21.6 & 21.6 & 5.6 & 5.9 \\
\hline Progeny & $H 1$ & $\overline{H 1}$ & $H 1$ & $H 1$ & 1.4 & 1.4 & 21 & 20.8 & 5.2 & 5.4 \\
\hline haplotypes & $\mathrm{H} 2$ & $\mathrm{H} 2$ & $\mathrm{H}_{2}$ & $\mathrm{H}_{2}$ & 1.9 & 1.8 & 22.7 & 23.2 & 6.6 & 7.0 \\
\hline \multirow[t]{2}{*}{ means } & $H 2$ & $H 2$ & $H 1$ & $H 1$ & 1.9 & 1.7 & 20.2 & 21.8 & 4.7 & 5.7 \\
\hline & $H 1$ & $H 1$ & $H 2$ & $H 2$ & 1.3 & 1.3 & 21.1 & 21.4 & 5.6 & 6.0 \\
\hline \multicolumn{11}{|c|}{ Selected individuals } \\
\hline 3533 & $H 2$ & $H 2$ & $H 2$ & $H 2$ & 3.5 & 2.2 & 22.9 & 23.3 & 6.5 & 6.9 \\
\hline 3546 & $H 2$ & $H 2$ & $H 2$ & $H 2$ & 3.2 & 2.9 & 24.1 & 24.1 & 6.9 & 6.9 \\
\hline 3556 & $H_{2}$ & $H_{2}$ & $H 2$ & $H 2$ & 3.4 & 1.9 & 23 & 23.7 & 6.4 & 7.3 \\
\hline 3560 & $H_{2}$ & $\mathrm{H}_{2}$ & $H 2$ & $H 2$ & 1.5 & 2.5 & 25.7 & 25.5 & 8.8 & 8.4 \\
\hline 3570 & $\mathrm{H}_{2}$ & $H_{2}$ & $H 2$ & $H 2$ & 1.8 & 2.1 & 22.9 & 25.7 & 6.0 & 9.0 \\
\hline 3572 & $\mathrm{H}_{2}$ & $\mathrm{H}_{2}$ & $\mathrm{H} 2$ & $\mathrm{H} 2$ & - & 3.3 & - & 29.1 & - & 10.5 \\
\hline
\end{tabular}

